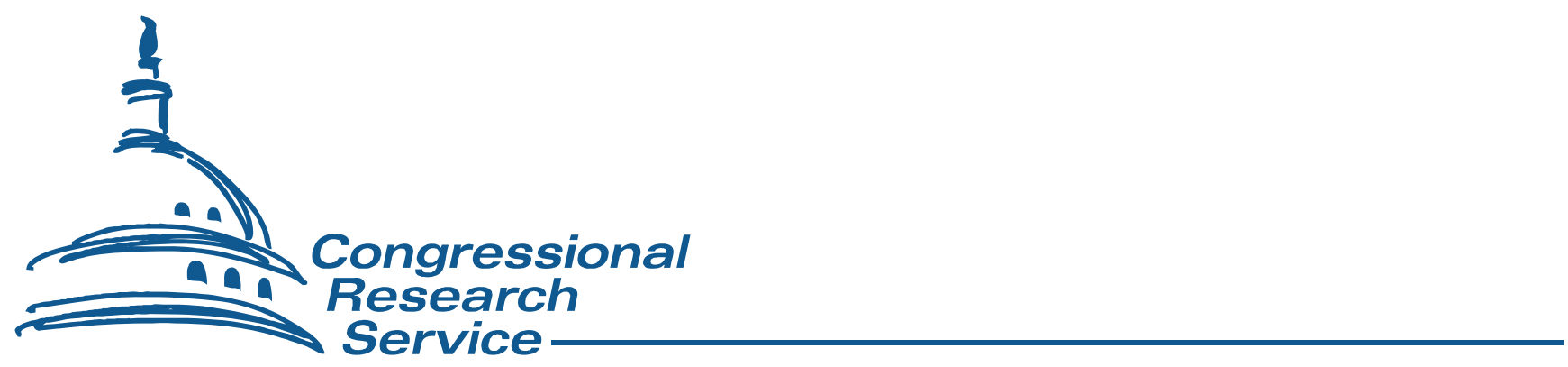

\title{
Super PACs in Federal Elections: Overview and Issues for Congress
}

\author{
R. Sam Garrett \\ Specialist in American National Government
}

September 12, 2012 


\section{Summary}

Super PACs emerged after the U.S. Supreme Court permitted unlimited corporate and union spending on elections in January 2010 (Citizens United v. Federal Election Commission). Although not directly addressed in that case, related, subsequent litigation (SpeechNow v. Federal Election Commission) and Federal Election Commission (FEC) activity gave rise to a new form of political committee. These entities, known as super PACs or independent-expenditure-only committees (IEOCs), have been permitted to accept unlimited contributions and make unlimited expenditures aimed at electing or defeating federal candidates. Super PACs may not contribute funds directly to federal candidates or parties.

This report explores what super PACs are, how they developed, what they raised and spent in the 2010 election cycle, and preliminary analysis of 2012 activity. As of this writing, Congress has not amended the Federal Election Campaign Act (FECA) to formally recognize the role of super PACs. No legislation introduced in the $112^{\text {th }}$ Congress focuses specifically on super PACs, but some bills contain relevant provisions. H.R. 3585 (Price, N.C.) proposes new disclaimer requirements that would apply to ads funded by super PACs and other entities. The same is true for a revised version of the DISCLOSE Act, H.R. 4010 (Van Hollen), introduced in the House in February 2012. Two Senate companion measures (S. 2219; S. 3369) have been introduced by Senator Whitehouse. The DISCLOSE Act would also require additional funding disclosure that could affect super PACs. The FEC has issued advisory opinions, but has not yet approved regulations on the subject.

Despite limited policy action on super PACs, these new entities are quickly occupying a major place in federal elections. In just 10 months of operation in 2010, almost 80 super PACs emerged, spending a total of approximately $\$ 90$ million-more than $\$ 60$ million of which went to elect or defeat federal candidates through independent expenditures. Super PAC financial activities appear likely to be even more ambitious in 2012. Approximately 600 super PACs are currently registered with the FEC. Some of the most prominent such groups are reportedly staffed by operatives with close ties to 2012 presidential campaigns. As of September 2012, the groups had reported spending more than $\$ 236$ million for the 2012 cycle. Various issues related to super PACs may be relevant as Congress considers how or whether to pursue legislation or oversight on the topic. These include relationships with other political committees and organizations, transparency, and independence from campaigns.

For those advocating their use, super PACs represent freedom for individuals, corporations, and unions to contribute as much as they wish for independent expenditures that advocate election or defeat of federal candidates. Opponents of super PACs contend that they represent a threat to the spirit of modern limits on campaign contributions designed to minimize potential corruption.

This report will be updated periodically to reflect major developments. 


\section{Contents}

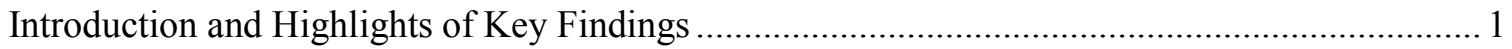

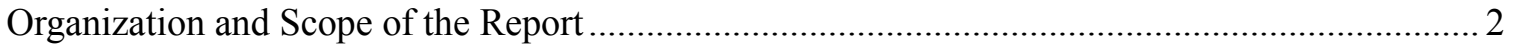

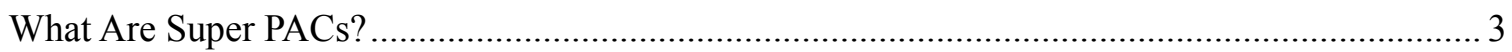

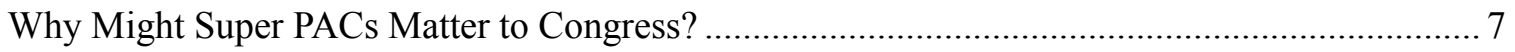

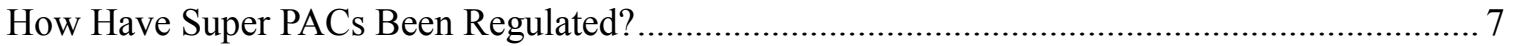

What Information Must Super PACs Disclose?....................................................................... 11

Overall, What Did Super PACs Raise and Spend in the 2010 Federal Elections?........................ 13

What Did Super PACs Spend Supporting or Opposing Congressional Candidates in

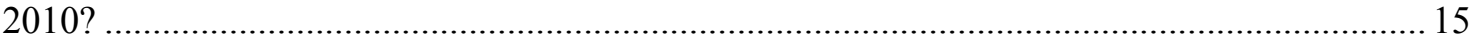

What Have Super PACs Raised and Spent So Far in 2012?................................................... 21

What Major Super PAC Issues Might Be on the Horizon?......................................................... 24

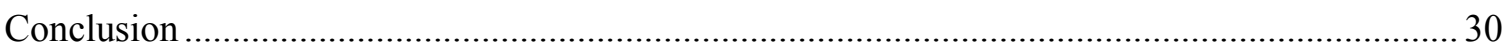

\section{Figures}

Figure 1. Top 10 Super PACs by Receipts and Disbursements, 2010

Figure 2. Support and Opposition for House Candidates in 2010 Super PAC Independent Expenditures

Figure 3. Support and Opposition for Senate Candidates in 2010 Super PAC Independent Expenditures

Figure 4. The 25 Congressional Races in 2010 in Which Super PACs Spent the Most on

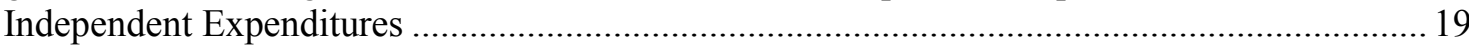

Figure 5. Super PACs Raising or Spending At Least \$1 Million in 2011 .................................... 22

Figure 6. Sample Disclosure for Corporations and Unions Using Direct Spending versus Contributions to Other Entities

\section{Tables}

Table 1. Basic Structure of Super PACs versus Other Political Committees and

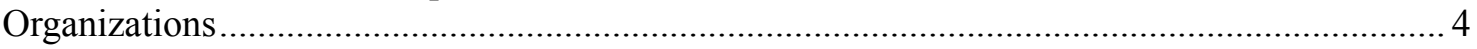

Table 2. Super PACs that Made At Least \$250,000 in Independent Expenditures in $2010 \ldots \ldots \ldots . .15$

Table 3. Overview of Campaigns Affected by 2010 Super PAC Independent Expenditures ........ 16

Table 4. The 25 Congressional Races in 2010 in Which Super PACs Spent the Most on Independent Expenditures

Table 5. The 10 Super PACs Reporting the Most Receipts and Disbursements for the 2012 Election Cycle 


\section{Appendixes}

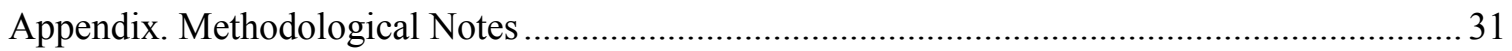

\section{Contacts}

Author Contact Information...... 


\section{Introduction and Highlights of Key Findings}

The development of super PACs is one of the most recent components of the debate over money and speech in elections. Some perceive super PACs as a positive consequence of deregulatory court decisions in Citizens United and related case SpeechNow. For those who advocate for super PACs, these new political committees provide an important outlet for political speech advocating independent calls for election or defeat of federal candidates. Others contend that they are the latest outlet for unlimited money in politics that, while legally independent, are functional extensions of one or more campaigns.

This report does not attempt to settle that debate, but it does provide context for understanding what the rapidly developing topic of super PACs might mean for federal campaign finance policy and federal elections. The report does so through a question-and-answer format with attention to super PAC activities in 2010, preliminary analysis of 2012-cycle data, and what those findings might mean looking ahead.

Selected findings and observations include the following points.

- Super PACs potentially have major policy and electoral consequences. A variety of issues related to the state of law and regulation affecting super PACs, disclosure, agency administration, and other topics might be relevant as Congress considers whether to pursue oversight or legislation.

- Additional regulation of super PACs might be attractive to those who believe that these organizations are thinly veiled extensions of individual campaigns. Those who believe super PACs are independent speakers might counter that super PACs' spending is not coordinated with campaigns and, therefore, should be subject to fewer disclosure requirements or other obligations than entities that can contribute to candidates.

- Most super PACs are financially modest, but a few raise and spend substantial sums. Ten super PACs accounted for almost $75 \%$ of all super PAC spending in 2010. A similar distinction has appeared thus far during the 2012 cycle. During 2011 - the first year of the 2012 cycle - 10 super PACs accounted for $72 \%$ of all super PAC spending.

- For the 2012 cycle, by September of that year super PACs had spent approximately $\$ 236$ million and appear to be poised to spend far more. They had raised more than $\$ 340$ million.

- Super PACs targeted their 2010 spending to favor particular parties and races. Most super PAC spending occurred in Senate races, where spending favored Republicans. Overall super PAC activity in House races favored Democrats. Thus far in 2012, the most prominent super PAC activity has surrounded specific presidential campaigns.

- Some individuals, corporations, and unions have made contributions exceeding hundreds of thousands of dollars, or even exceeding \$1 million, to super PACs supporting specific 2012 candidates. These contributions are permissible but, for some, raise concerns because of the way in which they are disclosed, because they would be impermissible if given directly to candidate campaigns, or both. 


\section{Organization and Scope of the Report}

Questions and answers about selected super PAC topics organize the following discussion. In particular:

- Brief Answer sections provide short summary information responding to each question.

- The Discussion following the brief answers expands on the analysis. These sections include bullet points designed to help the reader navigate the text.

- Tables and figures throughout the report summarize selected fundraising and spending data discussed in the text.

Before proceeding, readers should be aware of this report's scope and purpose. This report is intended to provide an overview of the developing role of super PACs in American elections, with an emphasis on summaries of available spending data and major policy issues that may face Congress. ${ }^{1}$ The report discusses selected litigation to demonstrate how those events have changed the campaign finance landscape and affected the policy issues that may confront Congress; it is not, however, a constitutional or legal analysis.

The report is also not intended to be a political analysis of strategic advantages or disadvantages surrounding the choice to form a super PAC, or of super PACs' effects on individual candidates. Fully addressing how super PACs affected individual races and candidates would require political analysis beyond the scope of this report. Nonetheless, understanding aggregate spending patterns in individual races (as opposed to campaigns) may assist Congress in its consideration of potential legislative, regulatory, or oversight responses.

Given the rapid development and frequently changing nature of super PACs, the report is not intended to address every organization or policy issue that may be relevant. It reflects current understanding of super PACs based on the analysis described throughout the report. Importantly, however, because federal election law and regulation have not been amended to address the role of super PACs, the findings presented here may be subject to alternative interpretations or future developments. Campaign finance data discussed in the report were collected and analyzed as noted in the text and discussed in the Appendix.

Finally, a note on terminology may be useful. The term independent expenditures (IEs) appears throughout the report. IEs refer to purchases, often for political advertising, that explicitly call for election or defeat of a clearly identified federal candidate (e.g., "vote for Smith," "vote against Jones"). Campaign finance lexicon typically refers to making IEs, which is synonymous with the act of spending funds for the purchase calling for election or defeat of a federal candidate. Parties, PACs, individuals, and now, super PACs, may make IEs. IEs are not considered campaign contributions and cannot be coordinated with the referenced candidate. ${ }^{2}$

\footnotetext{
${ }^{1}$ For a discussion of current campaign finance issues generally, see CRS Report R41542, The State of Campaign Finance Policy: Recent Developments and Issues for Congress, by R. Sam Garrett.

${ }^{2}$ On the definition of IEs, see 2 U.S.C. §431(17).
} 


\section{What Are Super PACs?}

\section{Brief Answer}

Super PACs first emerged in 2010 following two major court rulings that invalidated previous limits on contributions to traditional PACs. As a result of the rulings, in Citizens United and SpeechNow, new kinds of PACs devoted solely to making independent expenditures emerged. ${ }^{3}$ These groups are popularly known as super PACs; they are also known as independentexpenditure-only committees (IEOCs). Independent expenditures (IEs) are frequently used to purchase political advertising or fund related services (such as voter-canvassing). IEs include explicit calls for election or defeat of federal candidates but are not considered campaign contributions.

IEs must be made independent of parties and candidates. In campaign finance parlance, this means IEs cannot be coordinated with candidates or parties. Determining whether an expenditure is coordinated can be highly complex and depends on individual circumstances. ${ }^{4}$ In essence, however, barring those making IEs from coordinating with candidates means that the entity making the IE and the affected candidate may not communicate about certain strategic information or timing surrounding the IE. The goal here is to ensure that an IE is truly independent and does not provide a method for circumventing contribution limits simply because an entity other than the campaign is paying for an item or providing a service that could benefit the campaign.

Table 1 provides an overview of how super PACs compare with other political committees and political organizations. In brief, super PACs are both similar to and different from traditional PACs. Super PACs have the same reporting requirements as traditional PACs, and both entities are regulated primarily by the federal election law and the FEC as political committees. Unlike traditional PACs, super PACs cannot make contributions to candidate campaigns. Super PACs' abilities to accept unlimited contributions make them similar to organizations known as $527 \mathrm{~s}$ and some 501(c) organizations that often engage in political activity. ${ }^{5}$ However, while these groups are governed primarily by the Internal Revenue Code (IRC), super PACs are regulated primarily by the FEC. Unlike 527s as they are commonly described, super PACs are primarily regulated by the federal election law and regulation.

\footnotetext{
${ }^{3} 130$ S. Ct. 876 (2010); and 599 F.3d 686 (D.C. Cir. 2010) respectively.

${ }^{4}$ The discussion here is not intended to be exhaustive. For additional information, see, for example, 11. C.F.R. $\S 109.20$ and 11 C.F.R. $§ 109.21$.

${ }^{5}$ As the term is commonly used, 527 refers to groups registered with the Internal Revenue Service (IRS) as Section 527 political organizations that seemingly intend to influence federal elections in ways that may place them outside the FECA definition of a political committee. By contrast, political committees (which include candidate committees, party committees, and political action committees) are regulated by the FEC and federal election law. There is a debate regarding which 527s are required to register with the FEC as political committees. For additional discussion, see CRS Report RS22895, 527 Groups and Campaign Activity: Analysis Under Campaign Finance and Tax Laws, by L. Paige Whitaker and Erika K. Lunder. All political committees, including super PACs, are Section 527 political organizations for tax purposes.
} 
Table I. Basic Structure of Super PACs versus Other Political Committees and Organizations

(Refers to federal elections only)

\begin{tabular}{|c|c|c|c|c|c|c|}
\hline & $\begin{array}{l}\text { Is the entity } \\
\text { typically } \\
\text { considered a } \\
\text { political } \\
\text { committee by } \\
\text { the FEC? }\end{array}$ & $\begin{array}{c}\text { Must certain } \\
\text { contributors be } \\
\text { disclosed to the FEC? }\end{array}$ & $\begin{array}{l}\text { Can the entity make } \\
\text { contributions to } \\
\text { federal candidates? }\end{array}$ & $\begin{array}{l}\text { Are there limits on } \\
\text { the amount the entity } \\
\text { can contribute to } \\
\text { federal candidates? }\end{array}$ & $\begin{array}{c}\text { Can federal } \\
\text { candidates raise } \\
\text { funds the entity } \\
\text { plans to } \\
\text { contribute in } \\
\text { federal elections? }\end{array}$ & $\begin{array}{l}\text { Are there limits on } \\
\text { contributions the } \\
\text { entity may receive for } \\
\text { use in federal } \\
\text { elections? }\end{array}$ \\
\hline Super PACs & Yes & Yes & No & $\begin{array}{l}\text { Not permitted to make } \\
\text { federal contributions }\end{array}$ & $\begin{array}{l}\text { Yes, within FECA } \\
\text { limits }\end{array}$ & No \\
\hline “Traditional” PACs & Yes & Yes & Yes & $\begin{array}{l}\$ 5,000 \text { per candidate, } \\
\text { per election }\end{array}$ & $\begin{array}{l}\text { Yes, within FECA } \\
\text { limits }\end{array}$ & $\begin{array}{l}\$ 5,000 \text { annually from } \\
\text { individuals; other limits } \\
\text { established in FECA }{ }^{b}\end{array}$ \\
\hline Party Committees & Yes & Yes & Yes & $\begin{array}{l}\$ 5,000 \text { per candidate, } \\
\text { per election }\end{array}$ & $\begin{array}{l}\text { Yes, within FECA } \\
\text { limits }\end{array}$ & $\begin{array}{l}\$ 30,800 \text { from individuals; } \\
\text { other limits established } \\
\text { in FECA }\end{array}$ \\
\hline $\begin{array}{l}\text { Candidate } \\
\text { Committees }\end{array}$ & Yes & Yes & Yes & $\begin{array}{l}\$ 2,000 \text { per candidate, } \\
\text { per election }\end{array}$ & $\begin{array}{l}\text { Yes, within FECA } \\
\text { limits }\end{array}$ & $\begin{array}{l}\$ 2,500 \text { per candidate, } \\
\text { per election from } \\
\text { individuals; other limits } \\
\text { established in FECA }\end{array}$ \\
\hline $527 s^{c}$ & No & $\begin{array}{l}\text { No, unless independent } \\
\text { expenditures or } \\
\text { electioneering } \\
\text { communications }^{\mathrm{d}}\end{array}$ & No & $\begin{array}{l}\text { Not permitted to make } \\
\text { federal contributions }\end{array}$ & N/A & No \\
\hline $\begin{array}{l}50 I(c)(4) s,(5) s \\
(6) s^{\mathrm{e}}\end{array}$ & No & $\begin{array}{l}\text { No, unless independent } \\
\text { expenditures or } \\
\text { electioneering } \\
\text { communications }^{f}\end{array}$ & No & $\begin{array}{l}\text { Not permitted to make } \\
\text { federal contributions }\end{array}$ & N/A & No \\
\hline
\end{tabular}

Source: CRS adaptation from Table I in CRS Report R41542, The State of Campaign Finance Policy: Recent Developments and Issues for Congress, by R. Sam Garrett; and Federal Election Commission, "Contribution Limits for 20II-20I2," http://www.fec.gov/info/contriblimits I I 2.pdf.

Notes: The table does not include the following notes regarding additional limitations on contributions: (I) For individuals, a special biennial limit of $\$ 117,000$ ( $\$ 46,200$ to all candidate committees and $\$ 70,800$ to party and PAC committees) also applies. These amounts are adjusted biennially for inflation; (2) The national party committee and the national party Senate committee (e.g., the DNC and DSCC or RNC and NRSC) share a combined per-campaign limit of $\$ 43,100$, which is adjusted biennially for inflation.

a. This report uses the term traditional PACs to refer to PACs that are not super PACs. Here, the term includes separate segregated funds, nonconnected committees, and leadership PACs. The table assumes these PACs would be multicandidate committees. Multicandidate committees are those that have been registered with the FEC (or, for Senate committees, the Secretary of the Senate) for at least six months; have received federal contributions from more than 50 people; and (except for state 
parties) have made contributions to at least five federal candidates. See II C.F.R. §I00.5(e)(3). In practice, most PACs attain multicandidate status automatically over time.

b. As noted later in this report, nonconnected PACs utilizing an exemption per the Carey case may raise unlimited amounts for independent expenditures if those amounts are kept in a separate bank account and not used for contributions.

c. As the term is commonly used, 527 refers to groups registered with the Internal Revenue Service (IRS) as Section 527 political organizations that seemingly intend to influence federal elections in ways that place them outside the FECA definition of a political committee. By contrast, political committees (which include candidate committees, party committees, and political action committees) are regulated by the FEC and federal election law. There is a debate regarding which $527 \mathrm{~s}$ are required to register with the FEC as political committees. FEC contributor disclosure for these organizations applies only to those who designate their contributions for use in independent expenditures or electioneering communications. This table does not address general reporting obligations established in tax law or IRS regulations. For additional discussion, see CRS Report RS22895, 527 Groups and Campaign Activity: Analysis Under Campaign Finance and Tax Laws, by L. Paige Whitaker and Erika K. Lunder.

d. Federal tax law requires that 527 s periodically disclose to the IRS information about donors who have given at least $\$ 200$ during the year. See 26 U.S.C. $\$ 527(j)$. This information is publicly available. See 26 U.S.C. $\$ 6104$.

e. For additional discussion of these groups, see CRS Report RL33377, Tax-Exempt Organizations: Political Activity Restrictions and Disclosure Requirements, by Erika K. Lunder; and CRS Report R40I83, 50 I(c)(4) Organizations and Campaign Activity: Analysis Under Tax and Campaign Finance Laws, by Erika K. Lunder and L. Paige Whitaker.

f. Federal tax law requires that these groups disclose information to the IRS about donors who have given at least $\$ 5,000$ annually. See 26 U.S.C. $\$ 6033$. Unlike information on donors to political committees and 527s, however, this information is confidential and not made public. See 26 U.S.C. $\$ 6104$. 


\section{Discussion}

Super PACs originated from a combination of legal and regulatory developments. Most notably, in January 2010, the Supreme Court issued a decision in Citizens United v. Federal Election Commission. ${ }^{6}$ Citizens United did not directly address the topic of super PACs, but it set the stage for a later ruling that affected their development, as discussed below.

\section{Citizens United and SpeechNow}

As a consequence of Citizens United, corporations and unions are now free to use their treasury funds to air political advertisements explicitly calling for election or defeat of federal or state candidates (independent expenditures or $I E S$ ), or for advertisements that refer to those candidates during pre-election periods, but do not necessarily explicitly call for their election or defeat (electioneering communications). Previously, such advertising would generally have had to be financed through voluntary contributions raised by traditional PACs (those affiliated with unions or corporations, nonconnected committees, or both).

A second case paved the way for what would become super PACs. Following Citizens United, on March 26, 2010, the U.S. Court of Appeals for the District of Columbia held in SpeechNow.org v. Federal Election Commission ${ }^{7}$ that contributions to PACs that make only IEs - but not contributions - could not be constitutionally limited.

Also known as independent-expenditure-only committees (IEOCs), the media and other observers called these new political committees simply super PACs. The term signifies their structure akin to traditional PACs but without the contribution limits that bind traditional PACs. As discussed in the next section, after Citizens United and SpeechNow, the FEC issued advisory opinions that offered additional guidance on super PAC activities.

As the data discussed below show, the most obvious effects from super PACs are likely to be on the nation's electoral campaigns. By definition, super PACs are devoted to engaging in independent activities. They cannot ${ }^{8}$ make direct contributions to campaigns or coordinate their activities with campaigns. Nonetheless, super PACs could dramatically shape the environment affecting campaigns, particularly if they choose to engage in express advocacy that explicitly calls for election or defeat of particular candidates. In addition, despite prohibitions on coordination of their activities with campaigns, some observers have raised concerns that super PACs might not be independent of candidate campaigns in practice. ${ }^{9}$ Super PACs are treated as political committees and are regulated primarily by FECA and FEC regulations, unlike some

\footnotetext{
${ }^{6} 130$ S. Ct. 876 (2010). For additional discussion, see CRS Report R41045, The Constitutionality of Regulating Corporate Expenditures: A Brief Analysis of the Supreme Court Ruling in Citizens United v. FEC, by L. Paige Whitaker.

${ }^{7} 599$ F.3d 686 (D.C. Cir. 2010).

${ }^{8}$ Federal election law and FEC regulations have not been amended to clarify the role of super PACs. SpeechNow and related FEC advisory opinions have held that super PACs cannot make contributions to candidates or parties.

${ }^{9}$ This is particularly true, some argue, for super PACs that are believed to be organized primarily for supporting or opposing particular campaigns rather than several campaigns. See, for example, Fred Wertheimer, "Democracy Loses With Super PACs," Politico, September 28, 2011, p. 27.
} 
other "outside" spenders, such as organizations regulated primarily under Sections 527 and 501(c) of the Internal Revenue Code (IRC).

\section{Why Might Super PACs Matter to Congress?}

\section{Brief Answer}

The development of super PACs is one of the most recent chapters in the long-running debate over political spending and political speech. Super PACs potentially have major regulatory and electoral consequences. As data in this report show, super PACs have emerged quickly and have become a powerful spending force in federal elections. Nonetheless, as of this writing, federal election law and regulation have not been amended to formally recognize and clarify the role of super PACs. Congress may wish to consider the issue through legislation or oversight.

\section{Discussion}

Several policy issues and questions surrounding super PACs may be relevant as Congress considers how or whether to pursue legislation or oversight. These topics appear to fall into three broad categories:

- the state of law and regulation affecting super PACs,

- transparency surrounding super PACs, and

- how super PACs shape the campaign environment.

For those advocating their use, super PACs represent newfound (or restored) freedom for individuals, corporations, and unions to contribute as much as they wish for independent expenditures that advocate election or defeat of federal candidates. Opponents of super PACs contend that they represent a threat to the spirit of modern limits on campaign contributions designed to minimize potential corruption.

Additional discussion of these subjects appears throughout this report.

\section{How Have Super PACs Been Regulated?}

\section{Brief Answer}

Thus far, Congress has not enacted legislation specifically addressing super PACs. Existing regulations and law governing traditional PACs apply to super PACs in some cases. The FEC has issued advisory opinions on the topic but has not approved new regulations on super PACs.

\section{Discussion}

The FEC is responsible for administering civil enforcement of FECA and related federal election law. The commission began considering a notice of proposed rulemaking (NPRM) expected to 
address various Citizens United issues shortly after the Supreme Court's January 2010 decision. $^{10}$ After disagreement throughout 2011 and two previous deadlocked ${ }^{11}$ votes, in December 2011, commissioners approved a notice of proposed rulemaking (NPRM) posing questions about some aspects of what form post-Citizens United rules should take. ${ }^{12}$ Among other points, the agency essentially asks how broadly new rules should define permissible corporate and union independent expenditures and electioneering communications. It is unclear to what extent final rules, if adopted, will address super PACs.

Despite the lack of amendments to federal law or campaign finance regulation, the FEC has issued advisory opinions (AOs) that provided guidance on some super PAC questions. ${ }^{13}$ These AOs responded to questions posed by members of the regulated community, as those governed by campaign finance law are sometimes known, seeking clarification about how the commission believed campaign finance regulation and law applied to specific situations applicable to super PACs. Six AOs are particularly relevant for understanding how the FEC has interpreted the Citizens United and SpeechNow decisions with respect to super PACs, as briefly summarized below.

- In July 2010, the FEC approved two related AOs in response to questions from the Club for Growth (AO 2010-09) and Commonsense Ten (AO 2010-11). ${ }^{14}$ In light of Citizens United and SpeechNow, both organizations sought to form PACs that could solicit unlimited contributions to make independent expenditures (i.e., form super PACs). The commission determined that the organizations could do so. In both AOs, the commission advised that while post-Citizens United rules were being drafted, political committees intending to operate as super PACs could supplement their statements of organization (FEC form 1) with letters indicating their status. ${ }^{15}$ The major policy consequence of the Club for Growth and Commonsense Ten AOs was to permit, based on Citizens United and SpeechNow, super PACs to raise unlimited contributions supporting independent expenditures. ${ }^{16}$

\footnotetext{
${ }^{10}$ See, for example, Federal Election Commission, "FEC Statement on the Supreme Court's Decision in Citizens United v. FEC," press release, February 5, 2010, http://www.fec.gov/press/press2010/20100205CitizensUnited.shtml.

${ }^{11}$ The commission deadlocked in two 3-3 votes on draft NPRM documents 11-02, draft A, and 11-02-A, at the January 20, 2011, meeting. See Federal Election Commission, January 20, 2011, meeting minutes, pp. 4-5, http://www.fec.gov/ agenda/2011/approved2011_06.pdf. A vote to approve draft NPRM document 11-33 failed on a 2-4 vote at the June 15, 2011, commission meeting. At the same meeting, alternative draft NPRM document 11-33-A resulted in a deadlocked 3-3 vote. See Federal Election Commission, June 15, 2011, meeting minutes, pp. 3-4, http://www.fec.gov/agenda/2011/ approved2011_39.pdf. FECA requires that at least four commissioners vote affirmatively to approve NPRMs and final rules. For additional discussion, see CRS Report RS22780, The Federal Election Commission (FEC) With Fewer than Four Members: Overview of Policy Implications, by R. Sam Garrett.

${ }^{12}$ Federal Election Commission, "Independent Expenditures and Electioneering Communications by Corporations and Labor Organizations," 248 Federal Register 80803, December 27, 2011.

${ }^{13}$ AOs provide an opportunity to pose questions about how the commission interprets the applicability of FECA or FEC regulations to a specific situation (e.g., a planned campaign expenditure). AOs apply only to the requester and within specific circumstances, but can provide general guidance for those in similar situations. See 2 U.S.C. §437f.

${ }^{14}$ The AOs are available from the FEC website at http://saos.nictusa.com/saos/searchao.

${ }^{15}$ For sample letters, see Appendix A in AOs 2010-09 and 2010-11. A template is available at http://www.fec.gov/pdf/ forms/ie_only_letter.pdf.

${ }^{16}$ AOs do not have the force of regulation or law. Although AOs can provide guidance on similar circumstances in other settings, some may argue that AOs cannot, in and of themselves, create broad guidance about super PACs or other topics.
} 
- In June 2011, the commission approved an AO affecting super PAC fundraising. In the Majority PAC and House Majority PAC AO (AO 2011-12), the commission determined that federal candidates and party officials could solicit contributions for super PACs within limits. ${ }^{17}$ Specifically, the commission advised that contributions solicited by federal candidates and national party officials must be within the PAC contribution limits established in FECA (e.g., $\$ 5,000$ annually for individual contributions). ${ }^{18}$ It is possible, however, that federal candidates could attend fundraising events - but not solicit funds themselves - at which unlimited amounts were solicited by other people.

- In AO 2011-11, the commission responded to questions from comedian Stephen Colbert. Colbert's celebrity status generated national media attention surrounding the request, which also raised substantive policy questions. The Colbert request asked whether the comedian could promote his super PAC on his nightly television program, The Colbert Report. ${ }^{19}$ In particular, Colbert asked whether discussing the super PAC on his show would constitute in-kind contributions from Colbert Report distributor Viacom and related companies. An affirmative answer would trigger FEC reporting requirements in which the value of the airtime and production services would be disclosed as contributions from Viacom to the super PAC. Colbert also asked whether these contributions would be covered by the FEC's "press exemption," thereby avoiding reporting requirements. ${ }^{20}$ In brief, the commission determined that coverage of the super PAC and its activities aired on the Colbert Report would fall under the press exemption and need not be reported to the FEC. If Viacom provided services (e.g., producing commercials) referencing the super PAC for air in other settings, however, the commission determined that those communications would be reportable in-kind contributions. ${ }^{21}$ Viacom would also need to report costs incurred to administer the super PAC. ${ }^{22}$

- On December 1, 2011, the FEC considered a request from super PAC American Crossroads. In AO 2011-23, Crossroads sought permission to air broadcast ads featuring candidates discussing policy issues. American Crossroads volunteered that the planned ads would be "fully coordinated" with federal candidates ahead of the 2012 elections, but also noted that they would not contain express

\footnotetext{
${ }^{17}$ Majority PAC was formerly known as Commonsense Ten, the super PAC discussed above.

${ }^{18}$ On limitations on contributions to PACs, see Table 1 in CRS Report R41542, The State of Campaign Finance Policy: Recent Developments and Issues for Congress, by R. Sam Garrett. This section assumes a super PAC would achieve multicandidate committee status. Multicandidate committees are those that have been registered with the FEC (or, for Senate committees, the Secretary of the Senate) for at least six months; have received federal contributions from more than 50 people; and (except for state parties) have made contributions to at least five federal candidates. See 11 C.F.R. $\S 100.5(\mathrm{e})(3)$. In practice, most PACs attain multicandidate status automatically over time.

${ }^{19}$ Colbert's super PAC is popularly known as the Colbert Super PAC. It is registered with the FEC as Americans for a Better Tomorrow, Tomorrow. For a scholarly discussion, see R. Sam Garrett, "Seriously Funny: Understanding Campaign Finance Policy Through the Colbert Super PAC," Saint Louis University Law Journal, vol. 56, no. 3 (Spring 2012), pp. 711-723.

${ }^{20}$ On the press exemption, see 2 U.S.C. $\$ 431(9)(B)(i) ; 11$ C.F.R. $\S 100.73 ; 11$ C.F.R. $\S 100.132$; and discussion in AO 2011-11, pp. 6-8.

${ }^{21}$ See AO 2011-11, pp. 7-9. AOs are available from the FEC website at http://saos.nictusa.com/saos/searchao. ${ }^{22}$ Ibid., p. 9.
} 
advocacy calling for election or defeat of the candidates. ${ }^{23}$ In brief, the key question in the $\mathrm{AO}$ was whether Crossroads could fund and air such advertisements without running afoul of coordination restrictions designed to ensure that goods or services of financial value are not provided to campaigns in excess of federal contribution limits. ${ }^{24}$ (As a super PAC, Crossroads is prohibited from making campaign contributions; coordinated expenditures would be considered in-kind contributions.) Ultimately, the FEC was unable to reach a resolution to the $\mathrm{AO}$ request. In brief, at the open meeting at which the $\mathrm{AO}$ was considered, independent commissioner Stephen Walter and Democrats Cynthia Bauerly and Ellen Weintraub disagreed with their Republican counterparts, Caroline Hunter, Donald McGahn, and Matthew Petersen, about how FEC regulations and FECA should apply to the request. ${ }^{25}$ As a result of the 3-3 deadlocked vote, the question of super PAC sponsorship of "issue ads" featuring candidates appears to be unsettled. Although deadlocked votes are often interpreted as not granting permission for a planned campaign activity, some might also regard the deadlock as a failure to prohibit the activity. As a practical matter, if the FEC is unable to reach agreement on approving or prohibiting the conduct, it might also be unable to reach agreement on an enforcement action against a super PAC that pursued the kind of advertising Crossroads proposed.

- Also at its December 1, 2011, meeting, the FEC considered AO request 2011-21, submitted by the Constitutional Conservatives Fund PAC (CCF). CCF is a leadership PAC ${ }^{26}$ affiliated with Senator Mike Lee. CCF and other leadership PACs are not super PACs, although the CCF AO request is arguably relevant for super PACs. Specifically, in AO request 2011-21, CCF sought permission to raise unlimited funds for use in independent expenditures, as super PACs do. The FEC held, in a 6-0 vote, that because CCF is affiliated with a federal candidate, the PAC could not solicit unlimited contributions. To the extent that the CCF request is relevant for super PACs, it suggests that leadership PACs or other committees affiliated with federal candidates may not behave as super PACs.

To summarize, although the FEC has not yet issued rules regulating super PACs, AOs have provided guidance relevant for some circumstances. Perhaps most notably, through the Club for Growth (2010-09) and Commonsense Ten (2010-11) AOs, the commission confirmed that super

\footnotetext{
${ }^{23}$ See AO request (AOR) 2011-23, p. 5. The AOR was filed, as is typical, in a letter from the requester's counsel to the FEC General Counsel. See Letter from Thomas Josefiak and Michael Bayes to Anthony Herman, General Counsel, FEC, October 28, 2011, in the AO 2011-23 documents at at http://saos.nictusa.com/saos/searchao.

${ }^{24}$ Coordination is discussed later in this report. On coordination and the three-part regulatory test for coordination, see, respectively 2 U.S.C. $\$ 441 \mathrm{a}(\mathrm{a})(7)(B)$ and 11 C.F.R. $\$ 109.21$.

${ }^{25}$ Commissioners Bauerly and Weintraub issued a "statement of reasons" document explaining their rationale, as did Commissioner Walther and the three Republican commissioners. See Cynthia L. Bauerly and Ellen L. Weintraub, Statement on Advisory Opinion Request 2011-23 (American Crossroads), Federal Election Commission, Washington, DC, December 1, 2011; Steven T. Walther, Advisory Opinion Request 2011-23 (American Crossraods): Statement of Commissioner Steven T. Walther, Federal Election Commission, Washington, DC, December 1, 2011; and Caroline C. Hunter, Donald T. McGahn, and Matthew S. Petersen, Advisory Opinion Request 2011-23 (American Crossraods): Statement of Vice Chair Caroline C. Hunter and Commissioners Donald T. McGahn and Matthew S. Petersen, Federal Election Commission, Washington, DC, December 1, 2011.

${ }^{26}$ Leadership PACs are PACs affiliated with Members of Congress that provide an additional funding mechanism to support colleagues' campaigns. Although historically the purview of members of the House and Senate leadership, many Members of Congress now have leadership PACs. Leadership PACs are separate from the candidate's principal campaign committee.
} 
PACs could accept unlimited contributions and use those funds to make independent expenditures. In AO 2011-12 (Majority PAC and House Majority PAC), the commission granted permission for federal officeholders and party officials to solicit super PAC funds within the limits established in FECA. The Colbert AO (2011-11) applies to the relatively unique situation of a media personality discussing his super PAC on his television program. The Colbert AO may, nonetheless, have broad implications in the future by presenting a model for other media personalities and organizations to voice their support or opposition for political candidates, for media corporations to have greater latitude to support personalities who do so, or both. The FEC was unable to reach a consensus on American Crossroads' request (AO 2011-23) to air "issue ads" featuring candidates. Finally, in AO 2011-21, the commission determined that leadership PACs could not engage in unlimited fundraising for independent expenditures, as super PACs do.

\section{What Information Must Super PACs Disclose?}

\section{Brief Answer}

Super PACs must follow the same reporting requirements as traditional PACs. This includes filing statements of organization ${ }^{27}$ and regular financial reports detailing most contributions and expenditures.

\section{Discussion}

In the Commonsense Ten AO, the FEC advised super PACs to meet the same reporting obligations as PACs known as nonconnected committees (e.g., independent organizations that are not affiliated with a corporation or labor union). These reports are filed with the $\mathrm{FEC}^{28}$ and made available for public inspection in person or on the commission's website.

Super PACs and other political committees must regularly ${ }^{29}$ file reports with the $\mathrm{FEC}^{30}$ summarizing, among other things,

- total receipts and disbursements;

- the name, address, occupation, and employer ${ }^{31}$ of those who contribute more than $\$ 200$ in unique or aggregate contributions per year;

\footnotetext{
${ }^{27}$ This is FEC form 1. Essentially, it provides the FEC with information about how to contact the campaign and identifies the treasurer.

${ }^{28}$ Political committees devoted solely to Senate activities file reports with the Secretary of the Senate, who transmits them to the FEC for public positing. In theory, if a super PAC were devoted solely to affecting Senate campaigns, it is possible the super PAC would file with the Secretary rather than with the FEC. Nonetheless, the information would be transmitted to the FEC.

${ }^{29}$ Reporting typically occurs quarterly. Pre- and post-election reports must also be filed. Non-candidate committees may also file monthly reports. See, for example, 2 U.S.C. $\$ 434$ and the FEC's Campaign Guide series for additional discussion of reporting requirements.

${ }^{30}$ As noted previously, unlike other political committees, Senate political committees (e.g., a Senator's principal campaign committee) file reports with the Secretary of the Senate, who transmits them to the FEC. See 2 U.S.C. $\S 432(\mathrm{~g})$.

${ }^{31}$ The occupation and employer requirements apply to contributions from individuals.
} 
- the name and address of the recipient of disbursements exceeding $\$ 200 ; ;^{32}$ and

- the purpose of the disbursement. ${ }^{33}$

Reporting timetables for traditional PACs, which appear to apply to super PACs, depend on whether the PAC's activity occurs during an election year or non-election year.

- During election years, PACs may choose between filing monthly or quarterly reports. They also file pre- and post-general election reports and year-end reports. ${ }^{34}$

- During non-election years, PACs file FEC reports monthly or "semi-annually" to cover two six-month periods. The latter include two periods: (1) "mid-year" reports for January 1-June 30; and (2) "year-end" reports for July 1-December 31.35

Super PACs also have to report their IEs. ${ }^{36}$ IEs are reported separately from the regular financial reports discussed above. Among other requirements,

- independent expenditures aggregating at least $\$ 10,000$ must be reported to the FEC within 48 hours; 24-hour reports for independent expenditures of at least $\$ 1,000$ must be made during periods immediately preceding elections; ${ }^{37}$ and

- independent expenditure reports must include the name of the candidate in question and whether the expenditure supported or opposed the candidate. ${ }^{38}$

The name, address, occupation, and employer for those who contributed at least $\$ 200$ to the super PAC for IEs would be included in the regular financial reports discussed above, but donor information is not contained in the IE reports themselves. In addition, as the "Is Super PAC Activity Sufficiently Transparent?" section discusses later in this report, the original source of some contributions to super PACs can be concealed (either intentionally or coincidentally) by routing the funds through an intermediary.

\footnotetext{
${ }^{32}$ FECA contains some exceptions. For example, all disbursements used to make contributions to another political committee must be itemized, regardless of amount. See 2 U.S.C. $\$ 434(b)(4)$.

${ }^{33}$ FEC policy guidance has stated that "when considered along with the identity of the disbursement recipient, must be sufficiently specific to make the purpose of the disbursement clear." In general, however, political committees have broad leeway in describing the purpose of disbursements. For example, the commission has noted that generic terms such as "administrative expenses" are inadequate, but "salary" is sufficient. The quoted material and additional discussion appears in Federal Election Commission, "Statement of Policy: Purpose of Disbursement," 72 Federal Register 887-889, January 9, 2007.

${ }^{34}$ Quarterly reports are due to the FEC on April 15, July 15, and October 15. The final quarterly report is due January 31 of the next year. Monthly reports are due to the commission 20 days after the end of the previous month. The yearend report is due by January 31 of the year after the election. Pre-election reports summarizing activity for the final weeks of an election period must be filed with the FEC 12 days before the election. Monthly or quarterly reports are not required if their due dates fall near an otherwise required pre-election report. Post-general reports must be filed 30 days after the election; post-primary reports are not required. Additional requirements apply to special elections. See 11 C.F.R. $\S 104.5(\mathrm{c})(1)$.

${ }^{35}$ The reports are due to the FEC by July 31 and January 31 respectively. See 11 C.F.R. $\$ 104.5(c)(2)$.

${ }^{36}$ Separate reporting obligations apply to electioneering communications.

${ }^{37}$ See, for example, 2 U.S.C. $\$ 434(\mathrm{~g})$.

${ }^{38} 2$ U.S.C. $\$ 434(\mathrm{~g})(3)(\mathrm{B})$.
} 


\section{Overall, What Did Super PACs Raise and Spend in the 2010 Federal Elections?}

\section{Brief Answer}

Approximately 80 organizations quickly formed in response to the 2010 Citizens United and SpeechNow rulings. These first super PACs spent a total of approximately $\$ 90.4$ million, more than $\$ 60$ million of which was spent on IEs advocating for or against candidates. ${ }^{39}$ Just 10 super PACs accounted for almost $75 \%$ of all super PAC spending in $2010 .^{40}$

\section{Discussion}

To assess where and how super PACs became involved in House and Senate contests, CRS analyzed super PAC reports filed with the FEC. This section emphasizes total fundraising and spending reported to the commission for the entire 2010 election cycle. The next section explores activities in individual races and relies on those data most devoted to electing or defeating candidates - IE reports. The Appendix provides additional information about the methodology used to gather the data and conduct the analysis.

During the 2010 election cycle, 79 groups registered as super PACs spent a total of approximately $\$ 90.4$ million. This sum is perhaps notable not only for its size, but also because most of these organizations did not operate until the summer of $2010 .^{41}$ As Figure 1 shows, super PAC resources in 2010 were highly skewed, meaning that a relatively small number of groups accounted for a large amount of financial activity — both individually and as a proportion of all super PAC activity.

\footnotetext{
${ }^{39}$ Remaining amounts were apparently spent on items such as administrative expenses and non-federal races. IE totals range from approximately $\$ 61$ million to approximately $\$ 65$ million depending on whether one analyzes summary data provided by the FEC or sums individual IE filings. As discussed elsewhere in this report, various data sources and different filing schedules often yield slightly different numbers.

${ }^{40}$ The FEC provided CRS with data on spending by individual committees. The text in this section is based on CRS analysis of those data, including aggregating the totals and calculating percentages listed in the text.

${ }^{41}$ The FEC provided CRS with data on spending by individual committees. CRS aggregated the totals listed in the text. In the absence of additional regulations concerning registration for super PACs, it is not clear that all organizations are reflected in the figures in the text.
} 
Figure I.Top I 0 Super PACs by Receipts and Disbursements, 20 I 0

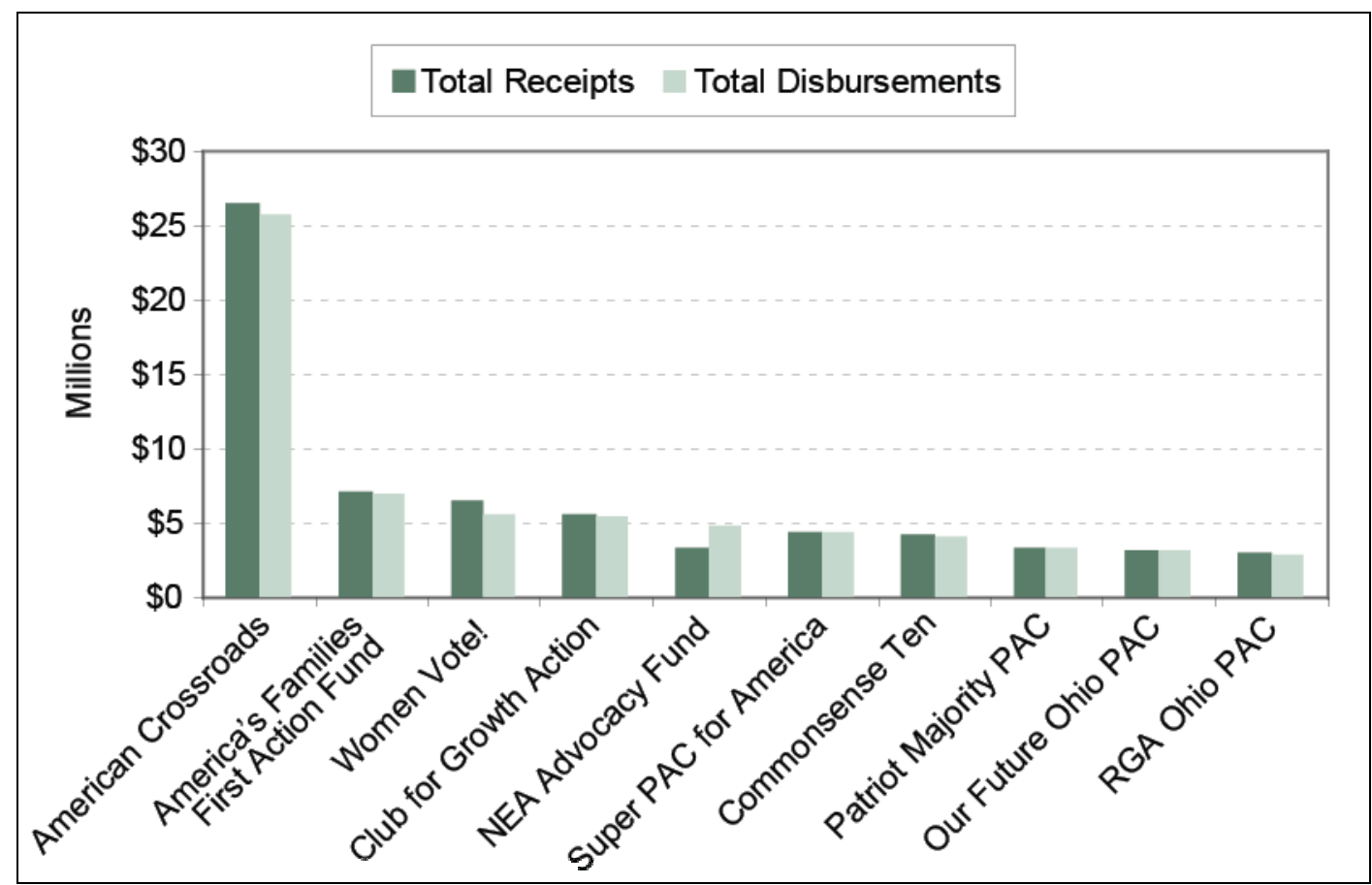

Source: CRS figure and analysis of data provided by the Federal Election Commission.

Notes: Amounts in the figure refer to total receipts and disbursements as reported to the FEC, not just independent expenditures.

Despite the fact that almost 80 super PACs registered with the FEC in 2010, just 10 accounted for almost $75 \%$ of these groups' total spending. Specifically, the 10-highest-spending super PACs in 2010 collectively spent approximately $\$ 66.8$ million, or $74 \%$ of the approximately $\$ 90$ million super PACs spent in total. ${ }^{42}$

A closer look reveals that it was not really 10 super PACs, but one, that spent a comparatively large amount in 2010. Specifically, American Crossroads single-handedly spent \$25.8 million, representing $28.7 \%$ of all super PAC spending. In other words, one super PAC (widely perceived as supporting Republicans) accounted for about one-third of all super PAC spending in 2010. American Crossroads' activity was so substantial that it spent more than three times the amount of second-ranked spender America's Families First Action Fund (which identifies as a Democratic organization).

\footnotetext{
${ }^{42}$ CRS calculated these totals and percentages based on FEC super PAC data for 2010. All figures are rounded compared with the original data. As noted previously, this section is based on total expenditures, not IEs.
} 


\section{What Did Super PACs Spend Supporting or Opposing Congressional Candidates in 2010?}

\section{Brief Answer}

Super PACs spent approximately $\$ 65.8$ million on IEs directly supporting or opposing federal candidates. Most of that spending was far more likely to oppose candidates than to support candidates. Specifically, more than $75 \%$ of super PAC IE spending in both House and Senate contests opposed candidates. Although about half of IE spending in House races opposed Republicans, about half of IE spending in Senate contests opposed Democrats.

\section{Discussion}

As noted above, super PACs spent approximately $\$ 90.4$ million in 2010 overall. Their independent expenditures - those expenses devoted to explicitly calling for election or defeat of a federal candidate and perhaps the best indicator of super PACs' influence in elections - accounted for about $70 \%$ of their spending.

Table 2 shows that almost 25 super PACs spent at least \$250,000 in IEs in 2010, but relatively few groups dominated - the same kind of divide among groups that appeared in total spending discussed above.

Table 2. Super PACs that Made At Least $\$ 250,000$ in Independent Expenditures in 2010

\begin{tabular}{lc}
\hline \multicolumn{1}{c}{ Committee Name } & Total Independent Expenditures \\
\hline AMERICAN CROSSROADS & $\$ 21,652,779$ \\
AMERICA'S FAMILIES FIRST ACTION FUND & $\$ 6,018,975$ \\
CLUB FOR GROWTH ACTION & $\$ 4,946,473$ \\
NEA ADVOCACY FUND & $\$ 4,200,000$ \\
WOMEN VOTE! & $\$ 3,614,066$ \\
COMMONSENSE TEN & $\$ 3,262,136$ \\
OUR FUTURE OHIO PAC & $\$ 3,158,139$ \\
SUPER PAC FOR AMERICA & $\$ 1,830,492$ \\
ALASKANS STANDING TOGETHER & $\$ 1,643,890$ \\
NEW PROSPERITY FOUNDATION; THE & $\$ 1,542,449$ \\
FIRST AMENDMENT ALLIANCE & $\$ 1,486,961$ \\
PATRIOT MAJORITY PAC & $\$ 1,239,955$ \\
ENDING SPENDING FUND & $\$ 1,150,000$ \\
NATIONAL ASSOCIATION OF REALTORS CONGRESSIONAL FUND & $\$ 1,097,266$ \\
MAJORITY ACTION PAC & $\$ 986,606$ \\
WORKING FOR US POLITICAL ACTION COMMITTEE INC & $\$ 881,558$
\end{tabular}




\begin{tabular}{lc}
\multicolumn{1}{c}{ Committee Name } & Total Independent Expenditures \\
\hline LEAGUE OF CONSERVATION VOTERS VICTORY FUND & $\$ 822,266$ \\
CONCERNED TAXPAYERS OF AMERICA & $\$ 789,452$ \\
AMERICAN WORKER INC, THE & $\$ 723,063$ \\
UNITED MINE WORKERS OF AMERICA POWER PAC & $\$ 330,830$ \\
20IO LEADERSHIP COUNCIL & $\$ 267,676$ \\
CITIZENS FOR A WORKING AMERICA PAC & $\$ 254,779$ \\
FLORIDA IS NOT FOR SALE & $\$ 250,472$ \\
\hline
\end{tabular}

Source: CRS analysis of data provided by the Federal Election Commission.

Notes: Committee names appear as listed in the FEC data. Data are from 2010 year-end reports. All figures are rounded compared with the original data. These figures could be affected by revised future filings or duplicate filings. The latter generally does not significantly affect the data overall.

A financial hierarchy of groups becomes more obvious when examining higher spending levels. Of 79 registered super PACs, only 14 (17.7\%) made more than \$1 million in IEs. As with the overall receipt and disbursement data, American Crossroads far outpaced all other super PACs, accounting for $\$ 21.7$ million in IEs and approximately one-third $(32.7 \%)$ of the total. America's Families First Action Fund again ranked second, having made $\$ 6$ million in IEs (or $9.1 \%$ of the total).

\section{Differences by Chamber and Party}

Table 3 shows how super PACs chose to prioritize their spending on House versus Senate contests. Of the approximately \$20 million super PACs spent on 2010 House IEs, almost half (46.2\%) went toward opposing Republicans. Further, 60.5\% (approximately $\$ 12$ million) favored Democrats by either opposing Republicans or supporting Democrats. ${ }^{43}$

Table 3. Overview of Campaigns Affected by 2010 Super PAC Independent Expenditures

\begin{tabular}{cccc}
\hline Chamber & Party & $\begin{array}{c}\text { Support or } \\
\text { Oppose }\end{array}$ & Total Spent \\
\hline HOUSE & DEMOCRATIC & OPPOSE & $\$ 6,062,723$ \\
& REPUBLICAN & SUPPORT & $\$ 2,869,324$ \\
& & OPPOSE & $\$ 9,239,555$ \\
SENATE & SEMOCRATIC & OPPORT & $\$ 1,813,919$ \\
& & SUPPORT & $\$ 20,525,502$ \\
& REPUBLICAN & OPPOSE & $\$ 1,246,055$ \\
& & SUPPORT & $\$ 7,060,514$ \\
\hline
\end{tabular}

${ }^{43}$ It should be noted, however, that some IEs ran in primary contests. 
Source: CRS analysis of 2010 Federal Election Commission independent expenditure reports.

Notes: Information in the table is as reported in FEC independent expenditure reports. CRS calculated information in the Total Spent column. The table excludes $\$ 241,298$ in independent expenditures made in opposition to a third-party House candidate (CO-4); and \$752, 100 made in opposition to a Florida Senate candidate whose party affiliation was listed as none in the FEC data.

Figure 2 and Figure 3 show that Super PAC spending in Senate races reflected essentially the opposite pattern found in spending on House races. Overall spending on IEs was also far higher for Senate races than for House races. Specifically, of approximately $\$ 40$ million spent on IEs for Senate contests, $51.2 \%$ (approximately $\$ 20.5$ million) opposed Democrats. An additional $17.6 \%$ (approximately $\$ 7$ million) supported Republicans.

To summarize, in 2010 super PACs spent about twice as much on Senate IEs as they did on House IEs. Slightly more than $60 \%$ of super PAC IE spending favored Democratic House candidates. In Senate races, almost 70\% favored Republicans.

\section{Figure 2. Support and Opposition for House Candidates in 2010 Super PAC Independent Expenditures}

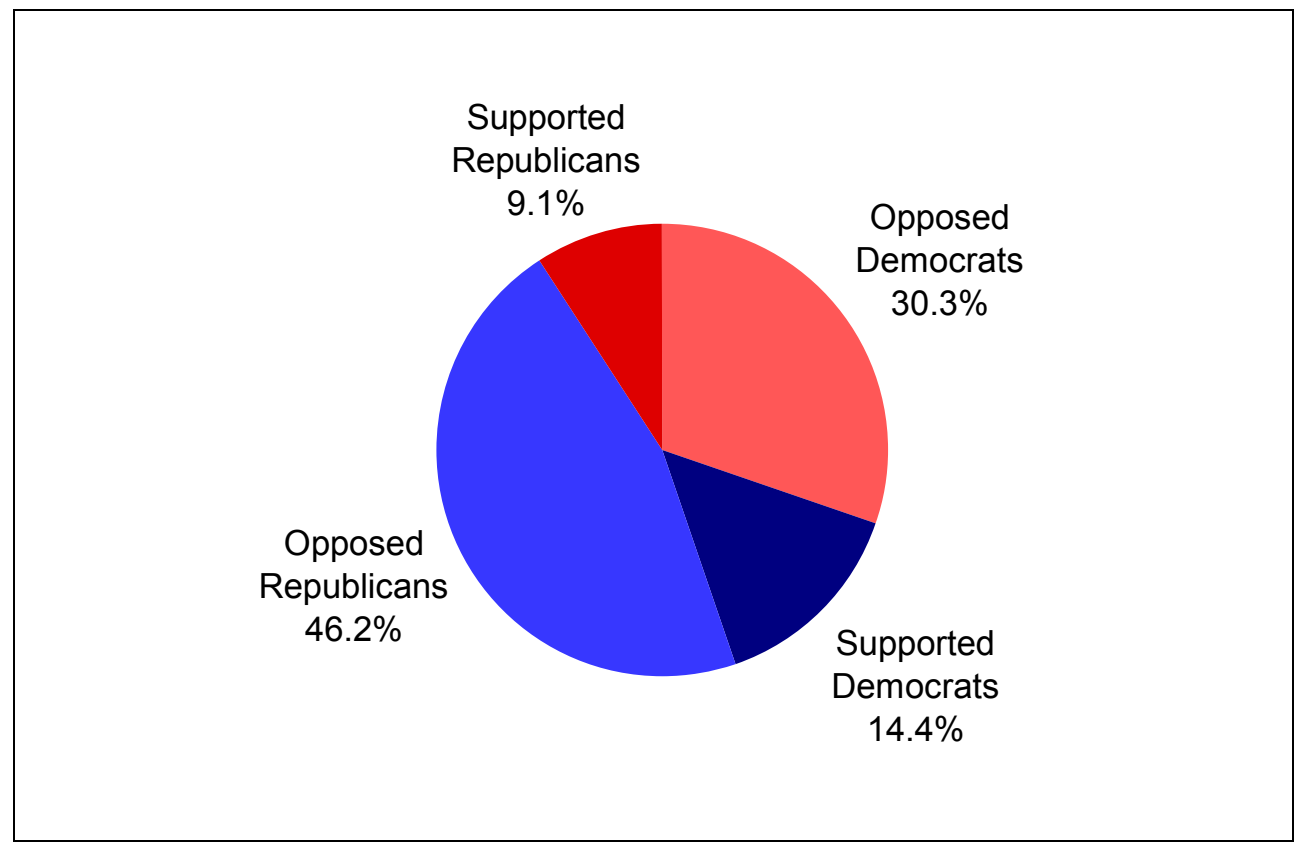

Source: CRS figure and analysis of Federal Election Commission independent expenditure reports.

Notes: Support and opposition labels are taken from independent expenditure reports. Percentages are based on dollar amounts spent, not number of expenditures. The figure excludes IEs made in opposition to a thirdparty House candidate (CO-4). 


\section{Figure 3. Support and Opposition for Senate Candidates in 2010 Super PAC Independent Expenditures}

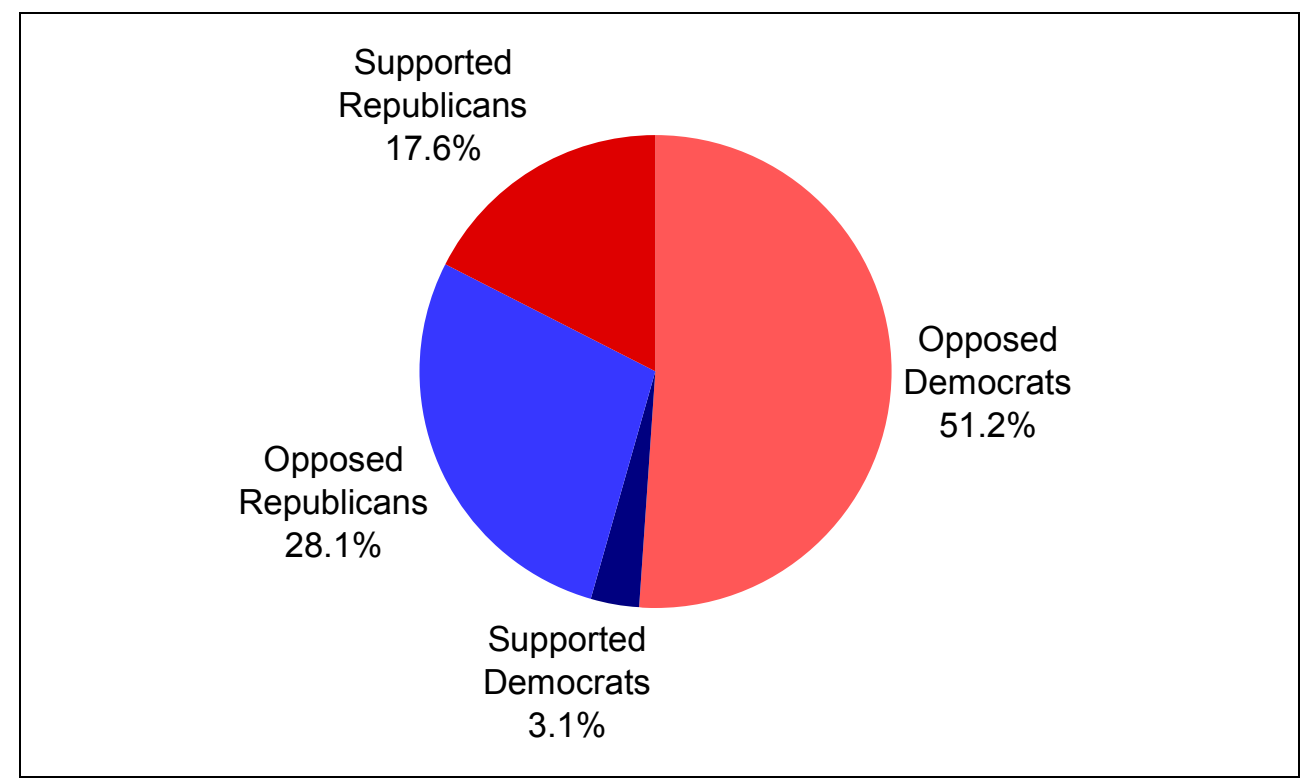

Source: CRS figure and analysis of Federal Election Commission independent expenditure reports.

Notes: Support and opposition labels are taken from independent expenditure reports. Percentages are based on dollar amounts spent, not number of expenditures. The figure excludes IEs made in opposition to a Florida Senate candidate whose party affiliation was listed as none in the FEC data.

\section{Most Super PAC IE Spending Targeted Relatively Few Races}

The preceding section shows that, overall, most super PAC spending occurred in Senate contests, and that a majority of that spending favored Republicans. Examining total spending on IEs in individual House and Senate contests provides more detail about where super PACs chose to become involved. Super PACs reported making IEs in 111 different House and Senate contests. Total super PAC IE spending in those races ranged from just \$1,100 (in a Kentucky House race) to more than $\$ 10$ million in the Colorado Senate contest. ${ }^{44}$

Not surprisingly, when super PACs chose to make IEs in 2010, they targeted their efforts carefully. In fact, the $\$ 10.1$ million super PACs spent on IEs in just one Senate race-in Colorado - accounted for $16.5 \%$ of all super PAC IEs spending in 2010. Of the approximately $\$ 60$ million super PACs spent in IEs overall in 2010, almost 60\% (\$37.4 million) were in the 10 Senate contests in which super PACs invested most heavily, as shown in the left side of Figure $4 .^{45}$

\footnotetext{
${ }^{44}$ This section only shows data in the figures and table for spending in the 25 contests in which super PACs spent the most on IEs. The underlying CRS analysis is based on all super PAC IE spending.

${ }^{45}$ These are the CO Senate through AK Senate entries on the left side of the figure.
} 


\section{Figure 4. The 25 Congressional Races in 2010 in Which Super PACs Spent the Most on Independent Expenditures}

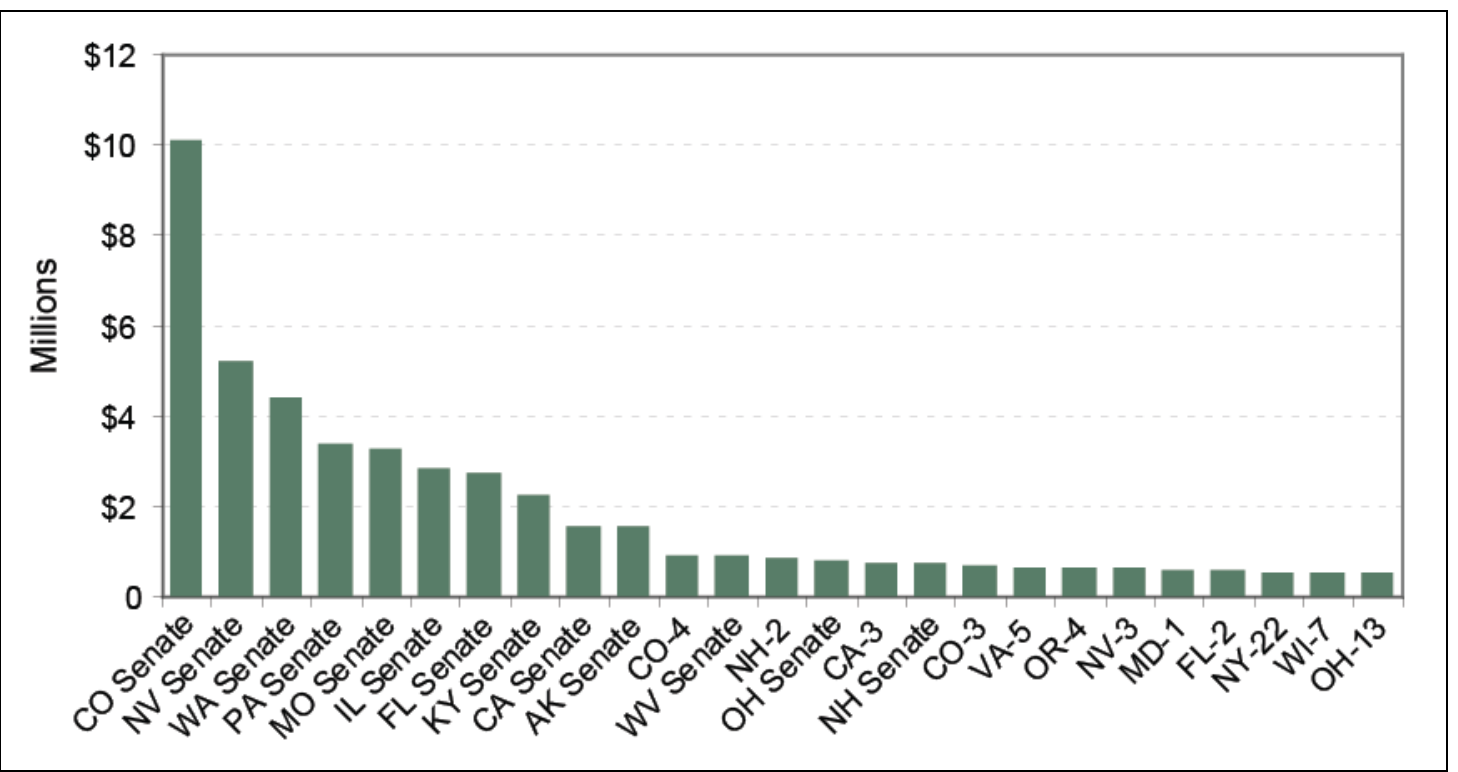

Source: CRS figure and analysis of Federal Election Commission independent expenditure reports.

As Table 4 shows, these were the 10 contests in which super PACs spent the most on IEs in 2010. When expanding the list to include the 25 races in which super PACs spent the most on IEs, the super PAC presence in House races becomes more apparent. Specifically, super PACs made IEs in 12 House races compared with 13 Senate contests.

In general, only a few super PACs chose to make IEs in each of the races shown in Table 4. Although not displayed in the table, the number of super PACs making IEs in these races ranged from one to eight groups per race, with a median of three groups per race. In other words, a small number of super PACs might be a major force in particular races.

Table 4. The 25 Congressional Races in 2010 in Which Super PACs Spent the Most on Independent Expenditures

\begin{tabular}{|c|c|c|c|c|c|}
\hline \multicolumn{2}{|c|}{ Races } & \multicolumn{4}{|c|}{ Super PAC Spending on Independent Expenditures } \\
\hline Race & $\begin{array}{c}\text { Total } \\
\text { Candidate } \\
\text { Spending }\end{array}$ & $\begin{array}{l}\text { Total Spent on } \\
\text { Super PAC IEs }\end{array}$ & $\begin{array}{l}\text { Favoring } \\
\text { Democrats }\end{array}$ & $\begin{array}{c}\text { Favoring } \\
\text { Republicans }\end{array}$ & $\begin{array}{c}\text { As a } \% \text { of Total } \\
\text { Candidate } \\
\text { Spending }\end{array}$ \\
\hline CO Senate & $\$ 24,768,060$ & $\$ 10,095,905$ & $26.1 \%$ & $73.9 \%$ & $40.8 \%$ \\
\hline NV Senate & $\$ 58,119,719$ & $\$ 5,240,671$ & $38.1 \%$ & $61.9 \%$ & $9.0 \%$ \\
\hline WA Senate & $\$ 26,380,159$ & $\$ 4,388,706$ & $74.6 \%$ & $25.4 \%$ & $16.6 \%$ \\
\hline PA Senate & $\$ 39,800,549$ & $\$ 3,371,370$ & $19.3 \%$ & $80.7 \%$ & $8.5 \%$ \\
\hline MO Senate & $\$ 22,589,367$ & $\$ 3,281,984$ & $18.2 \%$ & $81.8 \%$ & $14.5 \%$ \\
\hline IL Senate & $\$ 29,097,909$ & $\$ 2,853,403$ & $24.4 \%$ & $75.6 \%$ & $9.8 \%$ \\
\hline FL Senate* & $\$ 79,303,388$ & $\$ 2,730,132$ & $3.5 \%$ & $69.0 \%$ & $3.4 \%$ \\
\hline KY Senate & $\$ 18,947,679$ & $\$ 2,263,445$ & $24.9 \%$ & $75.1 \%$ & $11.9 \%$ \\
\hline
\end{tabular}




\begin{tabular}{|c|c|c|c|c|c|}
\hline \multicolumn{2}{|c|}{ Races } & \multicolumn{4}{|c|}{ Super PAC Spending on Independent Expenditures } \\
\hline Race & $\begin{array}{c}\text { Total } \\
\text { Candidate } \\
\text { Spending }\end{array}$ & $\begin{array}{l}\text { Total Spent on } \\
\text { Super PAC IEs }\end{array}$ & $\begin{array}{l}\text { Favoring } \\
\text { Democrats }\end{array}$ & $\begin{array}{c}\text { Favoring } \\
\text { Republicans }\end{array}$ & $\begin{array}{c}\text { As a } \% \text { of Total } \\
\text { Candidate } \\
\text { Spending }\end{array}$ \\
\hline CA Senate & $\$ 34,590,632$ & $\$ 1,572,560$ & $99.1 \%$ & $0.9 \%$ & $4.5 \%$ \\
\hline AK Senate & $\$ 6,880,323$ & $\$ 1,570,322$ & $0.0 \%$ & $100.0 \%$ & $22.8 \%$ \\
\hline $\mathrm{CO}-4^{*}$ & $\$ 6,272,648$ & $\$ 912,504$ & $73.6 \%$ & $0.0 \%$ & $14.5 \%$ \\
\hline WV Senate & $\$ 6,902,111$ & $\$ 900,374$ & $36.2 \%$ & $63.8 \%$ & $13.0 \%$ \\
\hline $\mathrm{NH}-2$ & $\$ 5,423,531$ & $\$ 849,400$ & $9.0 \%$ & $91.0 \%$ & $15.7 \%$ \\
\hline OH Senate & $\$ 14,322,287$ & $\$ 829,605$ & $1.1 \%$ & $98.9 \%$ & $5.8 \%$ \\
\hline CA-3 & $\$ 5,553,590$ & $\$ 738,601$ & $2.9 \%$ & $97.1 \%$ & $13.3 \%$ \\
\hline NH Senate & $\$ 19,50 \mid, 021$ & $\$ 730,434$ & $0.0 \%$ & $100.0 \%$ & $3.7 \%$ \\
\hline $\mathrm{CO}-3$ & $\$ 3,894,472$ & $\$ 706,318$ & $93.6 \%$ & $6.4 \%$ & $18.1 \%$ \\
\hline VA-5 & $\$ 7,512,617$ & $\$ 648,809$ & $100.0 \%$ & $0.0 \%$ & $8.6 \%$ \\
\hline OR-4 & $\$ 2,907,661$ & $\$ 628,115$ & $4.9 \%$ & $95.1 \%$ & $21.6 \%$ \\
\hline NV-3 & $\$ 4,569,261$ & $\$ 620,136$ & $89.1 \%$ & $10.9 \%$ & $13.6 \%$ \\
\hline MD-I & $\$ 5,57 I, 675$ & $\$ 592,278$ & $67.5 \%$ & $32.5 \%$ & $10.6 \%$ \\
\hline FL-2 & $\$ 5,755,620$ & $\$ 579,964$ & $78.5 \%$ & $21.5 \%$ & $10.1 \%$ \\
\hline NY-22 & $\$ 1,758,216$ & $\$ 533,584$ & $0.0 \%$ & $100.0 \%$ & $30.3 \%$ \\
\hline WI-7 & $\$ 3,647,216$ & $\$ 526,553$ & $95.3 \%$ & $4.7 \%$ & $14.4 \%$ \\
\hline $\mathrm{OH}-\mathrm{I} 3$ & $\$ 10,113,710$ & $\$ 521,442$ & $100.0 \%$ & $0.0 \%$ & $5.2 \%$ \\
\hline
\end{tabular}

Source: CRS analysis of Federal Election Commission independent expenditure reports (super PAC data); and CRS analysis of FEC summaries of candidate spending at http://www.fec.gov/disclosurehs/ hsnational.do;jsessionid=0B282B09E92062FFA I0932A8760 I C4CF.worker I.

Notes: CRS created the Favoring Democrats column by calculating the percentage of super PAC IEs that were reported as supporting Democrats or opposing Republicans; the Favoring Republicans column is the percentage of super PAC IEs reported as supporting Republicans or opposing Democrats.

*The table excludes $\$ 752,100$ made in opposition to a Florida Senate candidate whose party affiliation was listed as none in the FEC data. It also excludes $\$ 241,298$ in independent expenditures made in opposition to a thirdparty House candidate in CO-4.

\section{Super PAC IE Spending versus Candidate Spending}

One concern surrounding super PACs has been the possibility that their ability to spend unlimited sums could overwhelm candidates. As noted previously, a detailed understanding of how super PACs affected individual races or candidates would require political analysis that is beyond the scope of this report. In general, however, super PAC spending did not overwhelm candidate spending, even in the 25 races in which super PACs spent the most on IEs.

As Table 4 shows, even in the Colorado Senate race, where super PACs invested most, super PAC IEs did not eclipse candidate spending. Super PACs did, however, spend more than $40 \%$ as much as all candidates. Notably, the approximately $\$ 10$ million super PACs spent came from just seven groups. As the table shows, however, the Colorado case was atypical. In most races, super PACs spent less than $20 \%$ as much as candidates. 
The data also show that, in most races, super PAC spending on IEs heavily favored candidates from a single political party. In fact, in 12 of the 25 races shown in the table, $90 \%$ or more of IE spending favored one party over the other. In general, spending favored Republican candidates in the Senate and Democratic candidates in the House. Overall, super PAC IE spending in the 25 races in which super PACs invested most heavily favored Republican candidates (15 of 25 races).

In assessing the extent to which IEs favored one party over another, it is important to note that IE reports indicate only whether a candidate was supported or opposed, not whether one party was "favored" over another. As the Appendix explains, CRS created the favored party variable to measure how the cumulative effect of both opposing and supporting messages might affect candidates overall. The measure assumes that, for example, an IE opposing a Republican candidate advantages the Democratic opponent. This would not be so in all cases (such as in IEs aired during primary contests), but the approach might provide a more realistic assessment of the effects of IEs than simply examining support and opposition reports in isolation. Alternative methodologies might yield different results.

\section{What Have Super PACs Raised and Spent So Far in 2012?}

\section{Brief Answer}

Super PACs are playing an active role in the 2012 election cycle, especially in the Republican presidential primary campaign. The number of registered super PACs more than tripled between 2010 and early 2012 - from approximately 80 to approximately 250 groups that have indicated at least some financial activity as of this writing. In 2011, among groups that reported raising and spending funds, super PACs raised approximately $\$ 98.6$ million and spent approximately $\$ 38.5$ million. ${ }^{46}$ By early September 2012, approximately 600 super PACs were registered with the FEC. They reported spending approximately $\$ 236$ million and had raised more than $\$ 340$ million.

\section{Discussion}

Super PACs continued to grow in number and financial prominence following the 2010 election cycle. As during the 2010 cycle, it appears that a relatively small number of groups will again account for the majority of financial activity.

Even though the number of super PACs grew sharply - from 80 to approximately 600 between 2010 and 2012 (thus far) - many were not actively involved in fundraising or spending. In fact, only 130-140 super PACs reported raising or spending more than $\$ 0$ during 2011. Most that did exhibited relatively modest activity; these super PACs raised a median of approximately $\$ 31,000$ and spent a median of approximately $\$ 19,000$.

\footnotetext{
${ }^{46}$ Unless otherwise noted, information in this section comes from CRS analysis of year-end 2011 super PAC reports filed with the FEC. These figures include all activity, not only IEs. The analysis is based only on groups that reported raising or spending more than $\$ 0$ during 2011.
} 
Some groups, however, were substantially more active. Overall, during 2011 - the first year of the 2012 cycle - 10 super PACs accounted for $72 \%$ of all super PAC spending. In addition, as Figure 5 below shows, just 16 super PACs reported raising or spending at least $\$ 1$ million in 2011. Super PAC Restore Our Future, formed to support Governor Mitt Romney's presidential campaign, topped super PAC fundraising at \$30.2 million. Perhaps also notably, just as American Crossroads dominated super PAC activity in 2010, Restore Our Future was single-handedly responsible for about one-third (30.6\%) of 2011 super PAC fundraising. The group also led super PAC spending at \$6.6 million. At year's end, almost \$24 million remained in the bank and ready for 2012 spending. The most prominent Democratic super PAC, Priorities USA Action, reported raising and spending far less $-\$ 4.4$ million and \$2.9 million respectively. The Democratic group had \$1.6 million in cash on hand. ${ }^{47}$

Figure 5. Super PACs Raising or Spending At Least \$I Million in 201 I

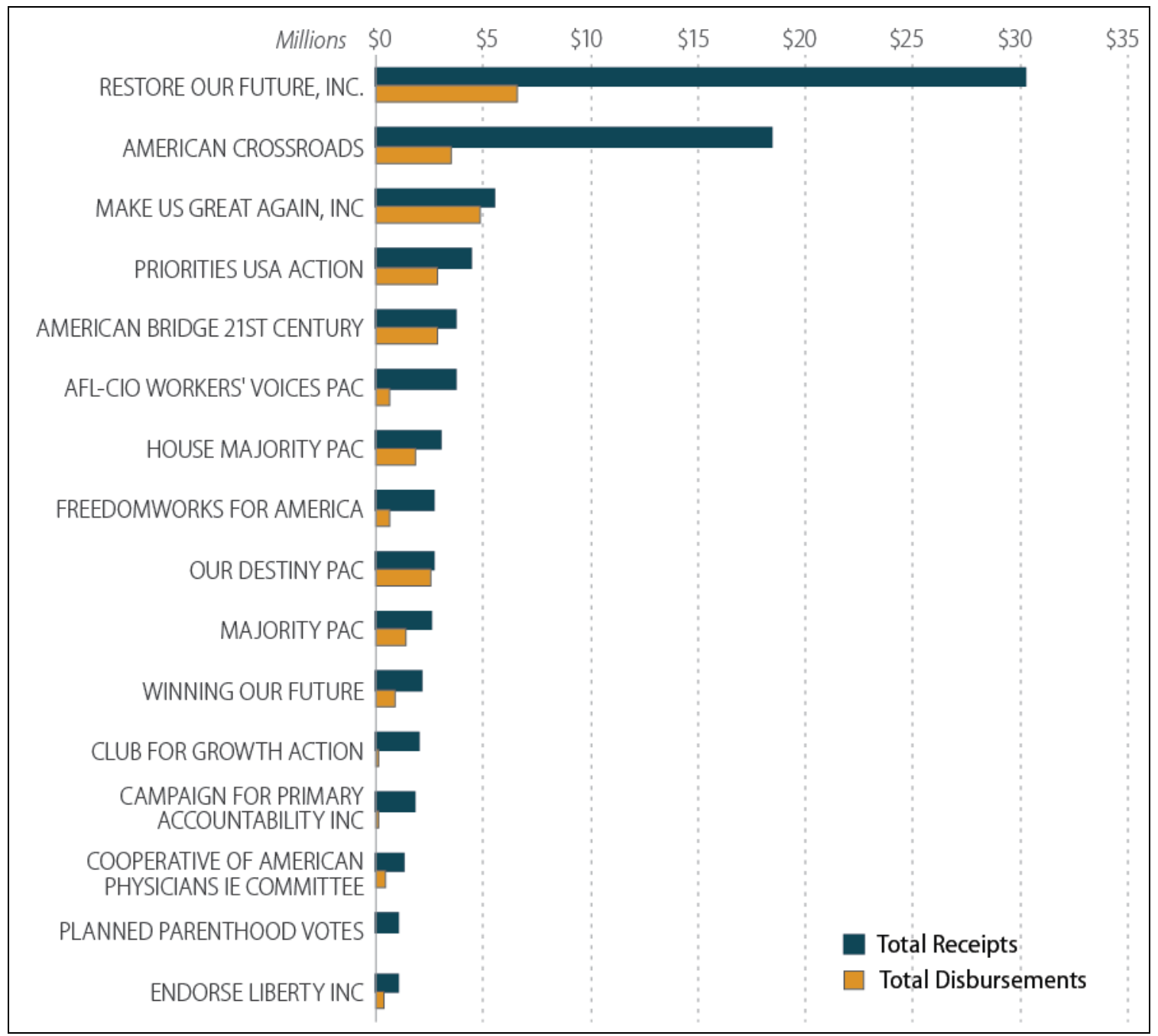

Source: CRS figure and analysis based on 2011 year-end reports filed with the FEC.

${ }^{47}$ Ibid. 
Notes: Analysis is based on 201 I data contained in the 2012 cycle "Committee Summary File," http://www.fec.gov/data/, as of February 2012. The analysis includes only those super PACs that reported raising or spending more than $\$ 0$ during $20 \mathrm{I}$ I. Amended filings or alternative analyses may yield different results.

Also potentially of note is the fact that some donors have provided large contributions to super PACs. In some cases, these include contributions that are permitted under Citizens United, but would be prohibited (because of the amount or source) as a contribution given directly to a campaign. For example, pro-Romney super PAC Restore Our Future received contributions from companies associated with cleaning-products firm Melaleuca, Inc. On August 5, 2011, Restore Our Future reported receiving four \$250,000 contributions from Melaleuca, Inc.; Melaleuca of Asia Ltd. Co.; Melaleuca of Japan, Inc.; and Melaleuca of Southeast Asia, Inc. (for a total of \$1 million). ${ }^{48}$ Similarly, Democratic super PAC Priorities USA Action reported receiving \$1 million in 2011 from union political action committee SEIU COPE. Both super PACs - and others - also reported large individual contributions. ${ }^{49}$

The distinction among groups continued as the 2012 elections neared. Analysis of 2012 super PAC activity reported to the FEC as of early September 2012 (reflecting filings through July 31) reveals the following:

- Super PACs reported spending approximately \$236 million and raising more than $\$ 340$ million. $^{50}$

- As occurred during the 2010 election cycle and 2011 calendar year, a relatively small number of super PACs continued to dominate.

- Thirty-six super PACs raised or spent at least $\$ 1$ million.

- These 36 super PACs accounted for the vast majority of all 2012-cycle super PAC activity. Specifically, they accounted for $90.8 \%$ of the $\$ 340.8$ million super PACs raised, and $90.7 \%$ of the $\$ 236.6$ million spent.

- Republican-oriented groups had a substantial advantage over Democraticoriented groups. Two particularly prominent groups-Restore Our Future and American Crossroads - reported raising more than \$136 million and spending more than $\$ 87$ million.

- Only 28 super PACs spent more than $\$ 1$ million during the cycle, and only five spent more than $\$ 10$ million.

Table 5 below summarizes financial activity of the 10 super PACs reporting the largest receipts and expenditures for 2012 through July 31 (the latest data available as of early September 2012). The table reports total disbursements rather than only IEs. Therefore, it is important to note that although these entities are raising and spending the most overall, other super PACs might have more direct impact on the election through higher spending on IEs that call for election or defeat of particular candidates.

\footnotetext{
48 This information appears in Restore Our Future's amended 2011 year-end report (FEC form 3X), Schedule A, image page numbers 12950442336-12950442337.

49 This information appears in Priorities USA Action's 2011 year-end report (FEC form 3X), Schedule A, image page number 12970340988.

${ }^{50}$ Information in this section is based on CRS analysis of super PAC filings contained in the FEC Committee Summary File.
} 
Table 5.The I 0 Super PACs Reporting the Most Receipts and Disbursements for the 2012 Election Cycle

\begin{tabular}{lcc}
\hline \multicolumn{1}{c}{ Committee Name } & Total Receipts & Total Disbursements \\
\hline RESTORE OUR FUTURE, INC. & $\$ 89,654,176$ & $\$ 69,149,391$ \\
AMERICAN CROSSROADS & $\$ 47,340,973$ & $\$ 18,616,910$ \\
PRIORITIES USA ACTION & $\$ 25,502,720$ & $\$ 21,276,856$ \\
WINNING OUR FUTURE & $\$ 23,921,215$ & $\$ 23,492,366$ \\
CLUB FOR GROWTH ACTION & $\$ 13,252,085$ & $\$ 10,916,818$ \\
MAJORITY PAC & $\$ 12,053,683$ & $\$ 8,770,327$ \\
HOUSE MAJORITY PAC & $\$ 9,593,781$ & $\$ 5,024,644$ \\
AMERICAN BRIDGE 2IST CENTURY & $\$ 8,633,258$ & $\$ 6,225,368$ \\
WORKERS' VOICE & $\$ 7,106,630$ & $\$ 5,230,653$ \\
CONGRESSIONAL LEADERSHIP FUND & $\$ 6,511,401$ & $\$ 223,723$ \\
\hline
\end{tabular}

Source: CRS analysis of super PAC data in the FEC Committee Summary File.

Notes: Committee names appear as listed in the FEC data accessed September 20I2, primarily reflecting filings as of July 3 I, 20I2. All figures are rounded compared with the original data. These figures could be affected by revised future filings or duplicate filings. Total disbursements include all expenditures, not only independent expenditures.

\section{What Major Super PAC Issues Might Be on the Horizon?}

\section{Brief Answer}

Because much about super PACs remains unknown, Congress might wish to conduct oversight or pursue legislative activity to clarify these new groups' place in federal elections. Super PAC activity might also be relevant for congressional oversight of the FEC as that agency continues to consider post-Citizens United rulemakings and reporting requirements. Looking ahead, questions about super PAC relationships with other organizations (particularly the issues of coordination and contribution limits), transparency, and their effect on the 2012 elections may be of particular interest.

\section{Discussion}

Super PACs address some of the most prominent and divisive issues in campaign finance policy. Most attention to super PACs is likely to emphasize their financial influence in elections, as is typically the case when new forces emerge on the campaign finance scene. Underlying that financial activity is law, regulation, or situational guidance (e.g., advisory opinions) — or the lack thereof-that shape how super PACs operate and are understood. 


\section{Policy Approaches}

As noted previously, despite Citizens United and SpeechNow, federal election law and FEC regulations have not, as of this writing, been amended to reflect the rise of super PACs. If Congress considers it important to recognize the role of super PACs in some way, it could amend FECA to do so. As it has generally done with other forms of PACs, Congress could also leave the matter to the FEC's regulatory discretion. ${ }^{51}$ The following points may be particularly relevant as Congress considers how or whether to proceed.

- Because advisory opinions do not have the force of regulation or law, the status of super PACs is arguably unsettled. Additional legislative or regulatory action to implement super PAC components of Citizens United and SpeechNow might provide additional clarity to those wishing to organize or contribute to super PACs.

- If Congress believes additional clarity would be beneficial, it could choose to enact legislation. This approach might be favored if Congress wishes to specify particular requirements surrounding super PACs, either by amending FECA, or by directing the FEC to draft rules on particular topics. Legislation has a potential advantage of allowing Congress to specify its preferences on its timetable. It has the potential disadvantage of falling short of sponsors' wishes if sufficient agreement cannot be found to enact the legislation. No legislation introduced in the $112^{\text {th }}$ Congress focuses specifically on super PACs, but some bills contain relevant provisions. H.R. 3585 (Price, N.C.) proposes new disclaimer requirements that would apply to ads funded by super PACs and other entities. The same is true for a revised version of the DISCLOSE Act, H.R. 4010 (Van Hollen), introduced in the House in February 2012. Senate companions, both introduced by Senator Whitehouse, include S. 2219 and S. 3369. Revised versions of the DISCLOSE Act would also require additional funding disclosure that could affect super PACs. In particular, original sources of super PAC funds that are today not necessarily transparent (as discussed elsewhere in this report) would have to be reported to the FEC. A CRS congressional distribution memorandum providing additional comparison of current and previous versions of the DISCLOSE Act is available to House and Senate requesters from the author of this report. $^{52}$

- As an alternative to legislation, Congress could choose to defer to the FEC (or perhaps other agencies, such as the IRS or SEC) with respect to new or amended rules affecting super PACs. This approach has the potential advantage of delegating a relatively technical issue to an agency (or agencies) most familiar with the topic, in addition to freeing Congress to pursue other agenda items. It

\footnotetext{
${ }^{51}$ For example, traditional PACs, known as separate segregated funds, originally arose from advisory opinions in the 1970s. Congress later incorporated the PAC concept into FECA amendments. For a historical overview, see, for example, Robert E. Mutch, Campaigns, Congress, and Courts: The Making of Federal Campaign Finance Law (New York: Praeger, 1988), pp. 152-185; and Anthony Corrado, "Money and Politics: A History of Federal Campaign Finance Law," in The New Campaign Finance Sourcebook, Anthony Corrado, Thomas E. Mann, Daniel R. Ortiz, and Trevor Potter (Washington: Brookings Institution Press, 2005), pp. 7-47.

${ }^{52}$ Comparison of Selected Versions of the DISCLOSE Act, by R. Sam Garrett, various dates, CRS congressional distribution memoranda. These memoranda are prepared for distribution to multiple congressional offices.
} 
has the potential disadvantage of producing results to which Congress might object, particularly if the six-member FEC deadlocks, as it has done on certain high-profile issues in recent years. The result could resemble the status quo, in which there are few definitive answers about how super PACs are regulated. If Congress chose the rulemaking approach, providing as explicit instructions as possible about the topics to be addressed and the scope of regulations could increase the chances of the rules reflecting congressional intent. Doing so might also increase the chances that consensus could be achieved during the implementation process.

\section{Potential Policy Questions and Issues for Consideration}

Despite some high profile activity in 2010 and 2012, much about super PACs remains unknown. This lack of knowledge is due to a combination of the fact that these entities are new players in elections and because the state of law and regulation surrounding the entities is arguably an open question. The following points may warrant consideration as the super PAC issue continues to emerge.

\section{What is the Relationship Between Super PACs and Other Political Committees or Organizations?}

As noted previously, the FEC considers super PACs to be political committees subject to the requirements and restrictions contained in FECA and FEC regulations. As such, super PACs are prohibited from coordinating their activities with campaigns or other political committees (e.g., parties). ${ }^{53}$ Particularly during the 2012 election cycle, some observers have raised questions about whether super PACs are really operating independently or whether their activities might violate the spirit of limits on contributions or coordination regulations. The following points may be relevant as Congress assesses where super PACs fit in the campaign environment.

- Concerns about super PAC independence appear to be motivated at least in part by the reported migration of some candidate campaign staff members to super PACs that have stated their support for these candidates. ${ }^{54}$

- A second source of concern may be that legally separate organizations (e.g., 501(c) tax-exempt political organizations, which are generally not regulated by the FEC or federal election law) operate alongside some super PACs. ${ }^{55}$ Media reports (and, it appears, popular sentiment) sometimes characterize these entities, despite their status as unique political committees or political organizations, as a single group. Questions have also emerged during the 2012 cycle about whether

\footnotetext{
${ }^{53}$ As noted previously, this report reflects common understanding of regulation and law as applied to super PACs. Subsequent changes in law or regulation that explicitly address super PACs could yield alternative findings.

${ }^{54}$ See, for example, Nicholas Confessore, "Lines Blur Between Candidates and PACs with Unlimited Cash," New York Times, August 27, 2011, p. A1; Steven Greenhouse, "A Campaign Finance Ruling Turned to Labor's Advantage," New York Times, September 26, 2011, p. A1; and Kenneth P. Vogel, "Super PACs' New Playground: 2012,” Politico, August 10, 2011, online edition retrieved via LexisNexis.

${ }^{55}$ For example, American Crossroads is a registered super PAC; Crossroads Grassroots Policy Strategies (GPS) is a 501(c)(4) tax-exempt organization. The same is reportedly true for perceived Democratic counterparts Priorities USA Action and Priorities USA, respectively. See, for example, the sources noted in the previous foot note; and Eliza Newlin Carney, "The Deregulated Campaign," CQ Weekly Report, September 19, 2011, p. 1922.
} 
some large contributions - that would be prohibited if they went to candidate campaigns - have essentially been routed through super PACs as IEs. Donors who wish to do so may now contribute to candidate campaigns in limited amounts and in unlimited amounts to super PACs supporting or opposing these or other candidates.

- As noted previously, super PACs must identify donors who contributed at least $\$ 200$. This requirement sheds light on contributions that go directly to super PACs, but not necessarily those that go indirectly to super PACs. In particular, the original source of contributions to trade associations or other organizations that later fund IEs through super PACs could go unreported. For example, assume Company A made a contribution to Trade Association B, and placed no restrictions on how the contribution could be used. Trade Association $B$ then used Company A's funds to contribute to a super PAC. Trade Association B-not Company A-would be reported as the donor on FEC reports. As Figure 6 below shows, an essential element in this relationship in this series of events is whether the original contribution was "made for the purpose of furthering" an independent expenditure. In practice, this means that those who do not wish their identities to be reported to the FEC could make an unrestricted donation to an intermediary organization, which then funnels the money to a super PAC. By contrast, if a corporation, union, or individual chose to contribute directly to a super PAC, or to make IEs itself, the entity's identity would have to be disclosed to the FEC.

\section{Figure 6. Sample Disclosure for Corporations and Unions Using Direct Spending versus Contributions to Other Entities}

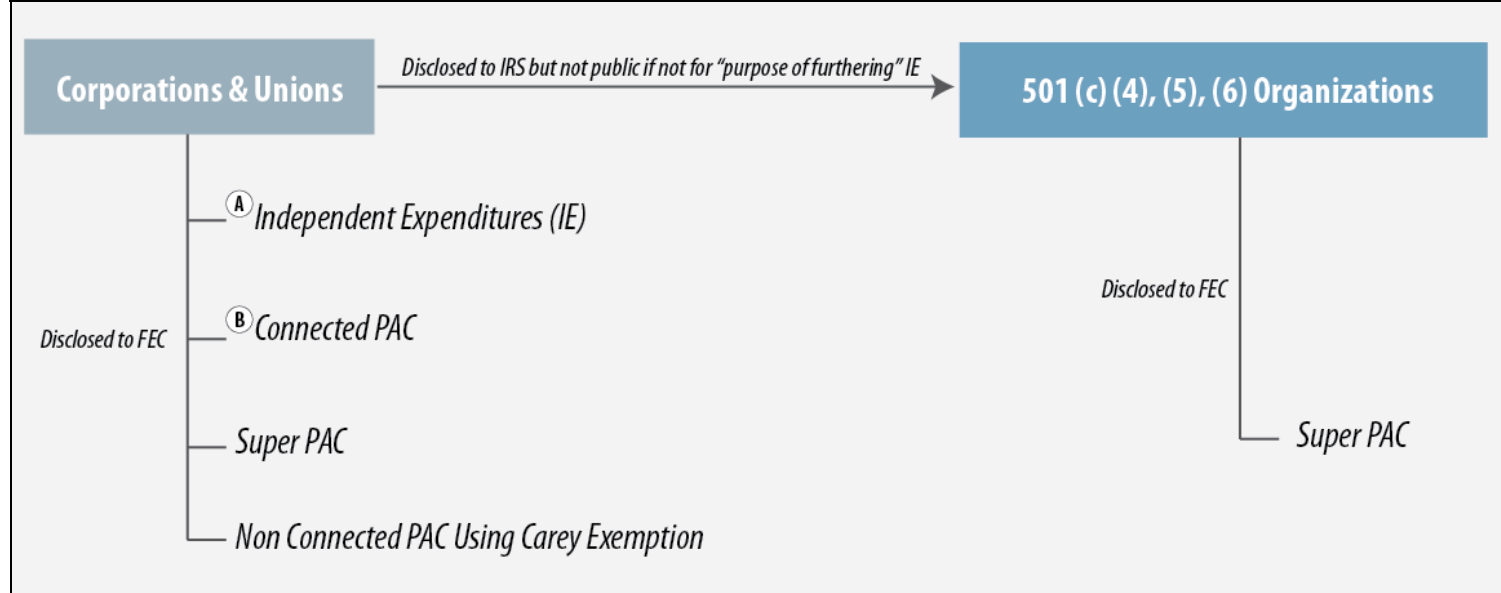

Source: CRS figure based on analysis of current disclosure requirements discussed throughout this report.

Notes: An individual could also spend funds as described in the left side of the figure (e.g., as could a corporation or union). The $50 \mathrm{I}$ (c) groups on the right side of the graph refer to social welfare organizations $[(\mathrm{c})(4) \mathrm{s}]$, unions [(c)(5)s], and trade associations (c)(6)s].

a. Reporting obligations would also apply to electioneering communications (ECs), if applicable.

b. A corporation or union could provide administrative support to a connected PAC, but contributions must come from voluntary donations raised subject to FECA limits.

- Because super PACs are prohibited from coordinating their activities with campaigns, Congress might or might not feel that gathering additional 
information about super PACs' independence is warranted. Whether or not super PACs are sufficiently independent and whether their activities are tantamount to contributions could be subject to substantial debate and would likely depend on individual circumstances.

- Concerns about the potential for allegedly improper coordination between super PACs and the candidates they favor are a prominent aspect of the debate thus far, but some might contend that more coordination would benefit super PACs and candidates by permitting them to have a unified agenda and message. Candidate frustration with "outside" spending is not unique to super PACs. Indeed, uncoordinated activities by traditional PACs, parties, and interest groups are a common occurrence in federal elections, although some contend that super PACs make concerns about outside messages increasingly urgent. ${ }^{56}$ Some observers contend that the ability to coordinate should, therefore, be increased. Others, however, warn that permitting more communication between outside groups and campaigns would facilitate circumventing limits on campaign contributions.

- As a general matter, it remains to be seen whether super PACs will compete with or complement other institutional actors in elections, particularly other entities that engage in independent expenditures, such as political parties. It is also unclear whether, over time, super PACs will primarily focus on multiple candidates or single candidates.

- Recent developments suggest that certain "traditional" PACs - not operating as super PACs - might be able to adapt some super PAC organizational characteristics for the 2012 election cycle and beyond. Specifically, in October 2011, the FEC announced that, in response to an agreement reached in a recent court case (Carey v. FEC ${ }^{57}$ ), the agency would permit nonconnected PACsthose that are unaffiliated with corporations or unions - to accept unlimited contributions for use in independent expenditures. The agency directed PACs choosing to do so to keep the IE contributions in a separate bank account from the one used to make contributions to federal candidates. ${ }^{58}$ As such, nonconnected PACs that want to raise unlimited sums for IEs are now able to create a separate bank account and meet additional reporting obligations rather than forming a separate super PAC. It remains to be seen how widely this practice will be adopted. Even if widespread, super PACs could continue to be an avenue for those other than nonconnected PACs (e.g., PACs connected to labor organizations or corporations, or groups of individuals) to engage in unlimited fundraising and spending on IEs.

\footnotetext{
${ }^{56}$ See, for example, Josh Boak, "Enter the Era of the Super PAC," Campaigns \& Elections, September 2011, online edition, http://www.campaignsandelections.com/magazine/us-edition/257312/enter-the-era-of-super-pacs.thtml. On campaign concerns about outside messages generally, see, for example, Michael John Burton and Daniel M. Shea. Campaign Mode: Strategic Vision in Congressional Elections (Lanham, MD: Rowman and Littlefield, 2003); R. Sam Garrett, Campaign Crises: Detours on the Road to Congress (Boulder, CO: Lynne Rienner Publishers, 2010); and Dancing Without Partners: How Candidates, Parties, and Interest Groups Interact in the Presidential Campaign, ed. David B. Magleby, J. Quin Monson, and Kelly D. Patterson (Lanham, MD: Rowman and Littlefield, 2007).

${ }^{57}$ Civ. No. 11-259-RMC (D.D.C. 2011).

${ }^{58}$ Federal Election Commission, "FEC Statement on Carey v. FEC: Reporting Guidance for Political Committees that Maintain a Non-Contribution Account," press release, October 5, 2011, http://www.fec.gov/press/Press2011/

20111006 postcarey.shtml.
} 


\section{Is Super PAC Activity Sufficiently Transparent?}

In addition to the organizational questions noted above - which may involve transparency concerns - Congress may be faced with examining whether enough information about super PACs is publicly available to meet the FECA goal of preventing real or apparent corruption. ${ }^{59}$ The following points may be particularly relevant as Congress considers transparency surrounding super PACs.

- In the absence of additional reporting requirements, or perhaps amendments clarifying the FEC's coordination ${ }^{60}$ rules, determining the professional networks that drive super PACs will likely be left to the media or self-reporting. In particular, relationships between super PACs and possibly related entities, such as 527 and 501(c) organizations, generally cannot be widely or reliably established based on current reporting requirements. ${ }^{61}$

- As the Appendix notes, and as is the case with most political committees, assessing super PAC financial activities generally requires using multiple kinds of reports filed with the FEC. Depending on when those reports are filed, it can be difficult to summarize all super PAC spending affecting federal elections. Due to amended filings, data can change frequently. Reconciling IE reports with other reports (e.g., those filed after an election) can also be challenging and require technical expertise. Streamlining reporting for super PACs might have benefits of making data more available for regulators and researchers. On the other hand, some may argue that because super PAC activities are independent, their reporting obligations should be less than for political committees making or receiving contributions.

- Because super PACs (and other PACs) may file semi-annual reports during nonelection years, information about potentially significant fundraising or spending activity might go publicly unreported for as long as six months. Consequently, some super PACs did not file detailed disclosure reports summarizing their 2011 activity until after the 2012 Iowa caucus and primaries in states such as New Hampshire, Florida, and South Carolina.

- Given the preceding points, a policy question for Congress may be whether the implications of the current reporting requirements represent "loopholes" that should be closed or whether existing requirements are sufficient. ${ }^{62}$ If additional

\footnotetext{
${ }^{59}$ For additional discussion of disclosure matters generally, see CRS Report R41542, The State of Campaign Finance Policy: Recent Developments and Issues for Congress, by R. Sam Garrett.

${ }^{60}$ See, for example, 11 CFR $\$ 109.20-11$ CFR $\$ 109.23$.

${ }^{61}$ See, for example CRS Report R41542, The State of Campaign Finance Policy: Recent Developments and Issues for Congress, by R. Sam Garrett; Eliza Newlin Carney, "The Deregulated Campaign," CQ Weekly Report, September 19, 2011, p. 1922; and Diane Freda, "Section 501(c)(4) Spending Expected to Hit New Records in 2012 Election," Daily Report for Executives, vol. 180 (September 16, 2011), p. J-1.

${ }^{62}$ Members of Congress have taken a variety of positions over the appropriate level of disclosure for political committees and other organizations in recent years. This is particularly true for what level of disclosure should be required for contributions to organizations making IEs or electioneering communications - perhaps most notably in recent years through the $111^{\text {th }}$ Congress debate over the DISCLOSE Act. See CRS Report R41264, The DISCLOSE Act: Overview and Analysis, by R. Sam Garrett, L. Paige Whitaker, and Erika K. Lunder. In the $112^{\text {th }}$ Congress, Representative Van Hollen filed a rulemaking petition with the FEC stating that the agency had improperly interpreted statute when writing regulations (11 C.F.R. $§ 109.10(e)$ ) that required disclosure of contributions supporting independent expenditures only if the contributions were made "for the purpose of furthering" the IEs. See Federal (continued...)
} 
information is desired, Congress or the FEC could revisit campaign finance law or regulation to require greater clarity about financial transactions. As with disclosure generally, the decision to revisit specific reporting requirements will likely be affected by how much detail is deemed necessary to prevent corruption or accomplish other goals.

\section{Conclusion}

Super PACs are only one element of modern campaigns. Regular media attention to super PACs might give an overstated impression of these organizations' influence in federal elections. Nonetheless - and notwithstanding that much about the organizations remains to be seen - there appears to be no shortage of individuals and organizations eager to form these new political committees that can raise and spend unlimited sums supporting or opposing federal candidates.

Super PACs join other groups in American politics, such as parties and 527 organizations, that are legally separate from the candidates they support or oppose, but whom some regard as practically an extension of the campaign. Questions of super PAC independence may be particularly relevant in 2012, as super PACs compete to elect or defeat congressional and presidential candidates. As with most campaign finance issues, whether Congress decides to take action on the super PAC issue, and how, will likely depend on the extent to which super PAC activities are viewed as an exercise in free speech by independent organizations versus thinly veiled extensions of individual campaigns. 


\section{Appendix. Methodological Notes}

The information about super PAC fundraising and spending contained in this report resulted from CRS analysis of FEC data. This appendix briefly discusses the methodology employed and notes caveats that may affect how the data are interpreted or replicated. Alternative approaches would likely yield different results. CRS consulted extensively with FEC staff about data matters. ${ }^{63}$

This report relies primarily on two data sources. Notes in the text, tables, and figures identify the data for each point of analysis. As explained in the text of the report, super PACs file at least two kinds of regular financial reports with the FEC: (1) monthly or semi-annual summaries of all fundraising and spending (FEC form $3 X$ and schedule $E^{64}$ ); and (2) 24- or 48-hour notices of independent expenditures (which may also be filed using schedule E). Because these reports cover different periods and are filed at different times, slight differences in fundraising and spending amounts are common. Reconciling the reports can be particularly challenging and timeconsuming, and may be of limited utility because differences between the two are usually small.

For the overall fundraising and spending amounts discussed in the report, the analysis relies on summaries of total fundraising and spending (derived from the $3 \mathrm{X}$ filings) provided by the FEC. The analysis of spending supporting or opposing candidates comes from the independent expenditure (IE) reports, which provide the clearest statements of super PAC spending favoring one candidate or another and which are filed in real-time. Amended or duplicate filings (which appear not to be a major factor in the data used in this report) may change the results if replicated in the future.

In the absence of additional reporting requirements, identifying super PACs currently requires the assumption that a super PAC has notified the FEC of its status by letter. To isolate super PAC spending on IEs, CRS accessed the entire 2010 IE data file (containing approximately 48,000 IE reports) and selected the approximately 1,200 made by organizations that had notified the commission of their super PAC status. ${ }^{65}$ Some cases of ambiguous organization names (e.g., various state-level chapters of a national organization or groups with similar names but different filing obligations) required consultation with FEC staff. It is possible that organizations that were excluded are, in fact, super PACs but filed reports incorrectly or not at all. Similarly, because data throughout the report rely on information reported to the FEC, an organization whose spending was too low to trigger disclosure requirements would not be reflected in the report. Therefore, the data exclude a presumably small amount of super PAC financial activity. Missing data might be exacerbated if a super PAC did not believe its activities required disclosure, or if, for example, it chose not to file until federal election law or regulations were amended to explicitly address super PACs.

CRS corrected super PAC and candidate name spellings, party affiliations, and support for or opposition to candidates in cases of obvious error or missing data (and where a clear answer

\footnotetext{
${ }^{63}$ In particular, this included FEC disclosure database analyst Paul Clark.

${ }^{64}$ Form $3 \mathrm{X}$ reports receipts and disbursements for entities other than authorized committees (e.g., PACs). Schedule E of form $3 \mathrm{X}$ reports itemized independent expenditures, including indications of support or opposition for specific candidates. Electronic versions of schedule E are known as Form 24.

${ }^{65}$ The remaining IEs were reported by entities such as traditional PACs, parties, or individuals.
} 
could be determined). CRS also disregarded the few cases of super PAC IE reports that appear to have been filed unnecessarily, such as those supporting state-level candidates.

For the analysis of spending on individual races, CRS standardized spellings of candidate names and the indicators for the districts or states in which they sought election. The total spending amounts and total IE amounts listed for the House and Senate races discussed are based on amounts from individual candidate reports contained on the FEC website, which CRS combined to yield totals for the entire race. These totals include primary and general election activity, and are listed as such on the FEC website.

CRS calculated the favored Democrats and favored Republicans amounts by totaling sums in IE reports listed as supporting or opposing candidates from each major party (e.g., favored Democrats includes expenditures reported as supporting Democrats or opposing Republicans). The favored measure arguably accounts for the overall effect of IE spending by examining both supportive and opposing messages that could benefit one candidate over another. The measure assumes that, for example, a negative message (reported as oppose) about a Republican candidate advantages the Democratic opponent. This would not be so in all cases (such as in IEs aired during primary contests). Overall, however, this approach may provide a more complete picture of super PAC activities than one that assumes advertising that supports or opposes one candidate has no effect on another.

This report does not attempt to assess the practical effect of these expenditures on individual candidates or to fully document their implications in individual races. As such, the spending discussed here should be regarded as one measure of super PAC activity, but not a comprehensive accounting of super PACs' electoral influence.

\section{A Note on 2012 Data}

Data for the 2012 cycle were assembled as described above from the latest available financial reports (e.g., 3Xs) filed with the FEC and contained in the agency's "committee summary file." This report will be updated as major developments warrant throughout the 2012 cycle, but it is not intended to serve as a detailed financial tracking report. Indeed, early developments in 2012 suggest that super PACs are making sufficient (and sufficiently large) independent expenditures in some cases that IE summaries published in this format would be quickly outdated. Additional data will be provided as events warrant and as stable, reliable data become available.

\section{Author Contact Information}

R. Sam Garrett Specialist in American National Government rgarrett@crs.loc.gov, 7-6443 